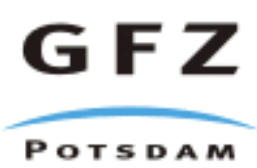

Originally published as:

Siegesmund, S., Heinrichs, T., Romer, R. L., Doman, D. (2007): Age constraints on the evolution of the Austroalpine basement to the south of the Tauern Window. - International Journal of Earth Sciences, 96, 3, 415-432,

DOI: 10.1007/s00531-006-0115-5. 


\title{
AGE CONSTRAINTS ON THE EVOLUTION OF THE AUSTROALPINE BASEMENT TO THE SOUTH OF THE TAUERN WINDOW
}

\author{
${ }^{1}$ SIEGFRIED SIEGESMUND, ${ }^{1}$ TILL HEINRICHS, ${ }^{2}$ ROLF L. ROMER \& ${ }^{1}$ DANIEL DOMAN
}

${ }^{1}$ Göttinger Zentrum Geowissenschaften, Goldschmidtstr. 3, 37077 Göttingen, Germany

${ }^{2}$ GeoForschungsZentrum Potsdam, Telegrafenberg, 14473 Potsdam, Germany

\begin{abstract}
The Austroalpine basement to the south of the Tauern Window once was part of the northern margin of Gondwana. It includes the "Altkristallin" and the phyllitic Thurntaler Complex. In the Altkristallin (AMU, MPU), suites of arc-related metamafic sequences occur together with calcalkaline metagranite. SHRIMP U-Pb dating of zircon from calc-alkaline metagranite associated with an eclogitic amphibolite give an age of $470 \pm 3 \mathrm{Ma}$ interpreted as the age of protolith emplacement. In the Thurntaler Complex, metaporphyroids occur together with tholeiitic as well as alkaline within-plate basalt-type metabasite. The metaryholites of this association give a crystallization SHRIMP-age of $477 \pm 4 \mathrm{Ma}$, which suggests contemporaneity of arc-related and extensional settings in the Austroalpine basement units. The age data demonstrate widespread magmatic activity associated with the Early-Ordovician amalgamation at the end of the 550-470 Ma subduction-accretion-collision cycle. The $\mathrm{Pb}-\mathrm{Pb}$ and U-Pb systematics of step-wise leached staurolite and kyanite from the peak-metamorphic assemblage of the Altkristallin indicate that (i) step-wise leaching of staurolite and kyanite yields the age of inclusions rather than the host; (ii) Zircon inclusions in staurolite suggest an Ordovician or older age for the precursor of the staurolite-schists; (iii) The weighted average of the ${ }^{206} \mathrm{~Pb} /{ }^{238} \mathrm{U}$ data of the various leaching steps yields a Variscan age for the inclusions (ilmenite, biotite, andesine). Since these inclusions are part of the metamorphic mineral assemblage, this age provides a minimum estimate for staurolite growth, i.e., metamorphism. Thus, the $\mathrm{Pb}-\mathrm{Pb}$ and $\mathrm{U}-\mathrm{Pb}$ systematics of staurolite provide
\end{abstract}


evidence for a Variscan metamorphism of the Austroalpine basement, e.g., MPU, AMU and Thurntaler Complex, to the south of the Tauern Window.

\section{Introduction}

Pre-Mesozoic basement areas form a major part of the Alps. The basement complex between the Tauern Window and the Pustertal-Line (see Fig. 1) belongs to the southern, proximal part of the Austroalpine nappes surrounding the Penninic Zone and the Tauern Window (for a compilation see Schulz et al. 1993, 2001). The geotectonic history of these basement units records the evolution of the northern margin of Gondwana and the northward drift of Avalonia and Armorica towards the southern margin of Laurentia and Baltica. The multistage pre-Alpine metamorphic and magmatic evolution is still under discussion (e.g., von Raumer and Neugebauer 1993; von Raumer 1998). The pre-Permian evolution of the Austroalpine basement units can be subdivided into different stages (e.g., von Raumer et al. 2002): The Late Precambrian to Early Palaeozoic evolution comprises sedimentation in an accretionary wedge environment with volcanic arc magmatism and possibly an early-Palaeozoic orogenic cycle prior to the intrusion of Ordovician granitoids (von Raumer 1998; von Raumer et al. 2002). Lowgrade metamorphic sediments and volcanic rocks (Ordovician - Devonian) document the rifting of the passive margin (e.g., Loeschke 1989; Loeschke and Heinisch 1993; Neubauer and Sassi 1993; Schönlaub 1993). Subsequent convergence of former peri-Gondwana continental blocks and Laurussia resulted in polyphase and complex crustal thickening, nappe stacking, and regionally variable metamorphic overprint during the Variscan orogeny.

In this paper, we focus on the Austroalpine basement to the south of the Tauern Window, the so-called "Zone der alten Gneise" (Sander 1929) or "Complesso Merano Mules Anterselva (Dal Piaz 1934). This "Altkristallin" is a pre-Ordovician clastic sedimentary sequence intruded by felsic plutons. The phyllitic units of the Thurntaler Complex, metamorphosed under greenschist to epidote-amphibolite facies conditions, recorded most probably the sedimentary evolution from the Lower Ordovician to the Upper Devonian. They may represent higher grade equivalents of the weakly metamorphosed sedimentary and volcanic rocks of the Greywacke Zone, the Gurktal Nappe Complex, and the Carnic Alps. 
Geochronology had a key position in deciphering the pre-Alpine evolution of the basement rocks of the Eastern Alps south of the Tauern Window (e.g., Borsi et al. 1973; Cliff 1980; Satir 1975; Hammerschmidt 1981; Klötzli 1995; Schulz and Bombach 2003). Pre-Variscan magmatic rocks include N-MORB-type basalts (now eclogitic amphibolites), basaltic arc type magmatites (now hornblende-plagioclase gneisses), and Ordovician felsic plutonic and volcanic rocks (now orthogneisses and metaporphyroids; Schulz et al. 2004). The Altkristallin underwent amphibolite-facies metamorphism, characterized by early crystallization of the pressuredominated mineral assemblages containing garnet, staurolite, and kyanite and later formation of sillimanite and andalusite. The polyphase deformation in a setting of noncoaxial shear resulted in sheath folds and later folding around steeply plunging axes. So far, structural observations and carboniferous mica ages (Borsi et al. 1978; Schuster et al. 2001; Steenken et al. 2002) represent the only evidence for Variscan metamorphism to the south of the Defereggen-Antholz-Vals (DAV) Line.

The ages of the pre-Alpine orogenic cycles in the Austroalpine basements are poorly constrained. To constrain the tectonometamorphic history of the "Altkristallin", accessory and minor rock forming minerals like zircon, staurolite, and kyanite were analyzed using SHRIMP techniques and $\mathrm{Pb} / \mathrm{Pb}$ step-wise leaching experiments respectively. For the interpretation of the geochronological data from step-wise leaching experiments, it is of particular interest to recognize that the age information is associated with micro-inclusions rather than the hosting staurolite. Our new data are discussed in the context of existing structural, petrological, and geochronological data.

\section{Geological setting}

Across the DAV Line, there is a step both in the age of metamorphism and the grade of Alpine metamorphism has been proposed. No Alpine ductile overprint can be observed to the south of this Line. Evidence for an Oligocene displacement along the DAV Line is provided by the syntectonic emplacement of the Rieserferner Pluton (Steenken et al. 2002; Romer and Siegesmund 2003).

The Eastern Alps to the south of the Tauern Window can be subdivided into four different 
tectonometamorphic units (Schulz et al. 1993; Fig. 1). A structurally lower metapsammopeliteamphibolite-marble unit (AMU), a monotonous upper metapsammopelitic unit (MPU), both forming the so-called classical "Altkristallin" of the basemet complex. Similar rock associations belong to the "Liegend-Komplex" and "Hangend-Komplex" of the Schober Group and form the Polinik and Strieden units of the central Kreuzeck Group, respectively. The presumably EarlyPalaezoic phyllitic Thurntaler Complex occurs at the southern margin of the Altkristallin, as well as in the Kreuzeck Group and Goldeck Group (Fig. 1). The fourth tectonometamorphic unit is part of the Gailtal metamorphic basement and consists of fossiliferous early-Palaezoic metasediments (Sprenger 1996). The Gailtal metamorphic complex is not investigated in this study.

In the following the tectono-lithostratigraphic units south of the Tauern Window are briefly described (following Schulz et al. 2001), although Schulz and Bombach (2003) redefined the tectono-lithostratigraphic units. See Fig. 1 for comparison of the here used nomenclature with the alternative one of Schulz and Bombach (2003).

\section{Amphibolite-marble unit (AMU)}

The AMU structurally overlies the Penninic rocks of the Matreier ophiolites and the Upper Schieferhülle adjacent to the Tauern units. The northern, lowermost part of the AMU is the Lasörling unit defined by Schönhofer (1999). It consists of biotite-muscovite gneisses, orthogneisses, and metamorphic mafic rocks. Farther to the south, there occur widespread garnet-muscovite and muscovite mica schists of the so-called mica schist group or Cima Dura unit. The southernmost part of the AMU (biotite gneiss series), which also defines the roof of the Rieserferner pluton, consists of biotite-rich gneisses, mica schists, and quartzitic paragneisses interlayered with marbles and in part with amphibolites and metapegmatoids.

In the Prijakt area (Schober Group), a $400 \mathrm{~m}$ thick mafic sequence (amphibolitized eclogites) is concordantly interlayered by strongly foliated orthogneisses, paragneisses, and mica schists. Schulz (1995) reported high pressure $\left(550-650^{\circ} \mathrm{C} / 14-16 \mathrm{kbar}\right)$ followed by high-temperature amphibolite facies metamorphism. Mafic rocks in the Schober Group include several groups with different geochemical signatures (Steenken and Siegesmund 2000; Schönhofer 1999; Schulz et al. 2001, 2004). 
A Rb-Sr whole-rock isochron of $445 \pm 24 \mathrm{Ma}$ (Hammerschmidt 1981) was interpreted as intrusion age of the felsic plutonic rocks (orthogneiss of Campo Tures/Sand i. T.). Schulz and Bombach (2003) reported U-Pb zircon evaporation ages around $590 \mathrm{Ma}$ for an eclogitic amphibolite and 550 - $530 \mathrm{Ma}$ for the hornblende-plagioclase gneisses. Rb-Sr (200-225 Ma) and $\mathrm{K}-\mathrm{Ar}$ (81-30 Ma) ages are discussed as mixing ages due to Variscan and Alpine overprints (e.g., Stöckhert 1982; Steenken et al. 2002). A compilation of age determinations is given in Table 1.

\section{Metapsammopelitic unit (MPU)}

The MPU is mainly composed of heterogeneous paragneisses intercalated with mica schists and orthogneisses. The paragneisses are highly variable in their quartz, mica, and feldspar content. The mica schists carry different amounts of garnet, kyanite, and staurolite. Calcsilicates and more rarely marbles, graphite-bearing gneisses and quartzites, as well as amphibolites do occur. The protoliths of the Antholz orthogneisses are highly peraluminous syncollisional S-type granitoids that were generated by partial anatexis of crustal protoliths. In contrast, Gsies-type orthogneisses are former peraluminous to metaluminous high-K granitoids that may have been derived from lower crustal rocks of a magmatic arc association.

Mineral assemblages of the mica schists in the MPU are characterized by biotite \pm muscovite \pm chlorite \pm staurolite \pm kyanite + oligoclase + quartz. The maximum P-T condition of $630^{\circ} \mathrm{C}$ and 6-11 kbar was obtained from Mg-rich rims of garnet (Schulz 1997; Schulz et al. 2001).

Conventional multigrain zircon $\mathrm{U}-\mathrm{Pb}$ ages at $443 \pm 16 \mathrm{Ma}$ and $424 \pm 11 \mathrm{Ma}$ from biotite and muscovite bearing orthogneisses, respectively, were interpreted as intrusion ages (Cliff 1980). For the orthogneisses in the MPU Klötzli (1995) discusses two magmatic events (see Table 1). Whereas these radiometric data were interpreted to date the emplacement of the granitoid bodies into Pre-Upper-Ordovician basement, Schulz and Bombach (2003) found older ${ }^{207} \mathrm{~Pb} /{ }^{206} \mathrm{~Pb}-$ single zircon evaporation ages for orthogneisses (471 to $448 \mathrm{Ma}$ ). Variscan metamorphism is indicated by $\mathrm{Rb}-\mathrm{Sr}$ and $\mathrm{K}-\mathrm{Ar}$ mica ages ranging from 250 to $310 \mathrm{Ma}$ for the para- and orthogneisses to the south of the DAV Line (Borsi et al. 1973, 1978; Satir 1975; Steenken et al. 2002). In addition, Schuster et al. (2001) found geochronological evidence for a Permo-Triassic HT/LP metamorphic event. 


\section{$\underline{\text { Thurntaler Complex }}$}

The boundary between the MPU of the Altkristallin and the Thurntaler Complex is still under debate. Based on new mapping, this boundary seems to be transitional with the exception of the Markinkele area, where mylonites overprint the lithological contact (Heinisch and Schmidt 1984; Schulz 1991; Schulz et al. 2001). Kreutzer (1992) noticed a much higher chlorite content in the fine-grained mica schists of the Thurntaler Complex compared to those of the Altkristallin.

The Thurntaler Complex consists mainly of quartz phyllites, mica schists, amphibolites, epidote-amphibolites, chlorite mica schists, and rare marbles (Krol 1974; Heinisch and Schmidt 1984; Kreutzer 1992). Most characteristic for this lithostratigraphic correlation are stratiform $\mathrm{Cu}-$ and Sn-W-mineralizations as well as porphyroid gneisses (Krol 1974; Heinisch and Schmidt 1976). The latter ones are characterized by alkali-rhyolitic, rhyolitic, and dacitic compositions and may have been deposited in a marine environment. The geochemical composition and structures of these porphyroids are similar to Upper Ordovician rocks elsewhere in the AustroAlpine basement. Therefore, these rocks were considered to be the volcanic equivalents of the Late Ordovician felsic magmatism in the adjacent AMU and MPU (Peccerillo et al. 1979; Schönlaub 1979; Heinisch 1981; Heinisch and Schmidt 1982).

The metamorphic peak conditions at c. $600^{\circ} \mathrm{C}$ and c. $6 \mathrm{kbar}$ for the amphibolites are obtained on strongly zoned amphiboles with actinolite cores and green hornblende rims (Schulz 1991). Based on P-T-data and the quasi-concordant lithological contact, Schulz (1991) concluded that the tectonic juxtaposition of the TC on the MPU took place after the penetrative D2 event.

Lithological comparison with dated lithologies of the Eastern Alps was used to infer an Ordovician to Early Devonian age for these rocks (e.g. Sassi et al. 1985; Heinisch and Schmidt 1976, 1984; Schönlaub 1979; Schulz 1991; Kreutzer 1992). For the meta prophyroid protolith, Schulz and Bombach (2003) determined ${ }^{207} \mathrm{~Pb} /{ }^{206} \mathrm{~Pb}$ evaporation ages of $473-469 \mathrm{Ma}$ on zircon.

\section{Results of age determinations}




\section{Zircon}

Sample BS3 (Fig. 2a) is an orthogneiss from the Prijakt area of the Schober Group. It is part of the "Hangendserie" (Clar 1972), i.e., the AMU. This strongly foliated orthogneiss is one of a number of intercalations within metabasic rocks, which are commonly referred to as "eclogitic amphibolites" (Troll et al. 1976, 1980). The orthogneiss sample BS3 yielded a large number of clear colorless to slightly yellow, generally subhedral zircon crystals that show only minor rounding of the crystal edges. Acicular inclusions of apatite are common and some zircon grains are fractured and re-sealed by subsequent growth. Cathodoluminescense (CL) imaging reveals complex growth patterns characterized by magmatic growth zoning enclosing rounded or partially resorbed cores (Figs. 3a and 3b). Textural discontinuities of the magmatic zoning indicate resorption intervals during crystal growth. A narrow outermost rim, containing brightCL veins, is present in most zircon crystals and may reflect recrystallization or alteration during a metamorphic event. SHRIMP-analyses were performed on sixteen zircon crystals from orthogneiss BS3. The data are presented in Table 2 and plotted in a Tera-Wasserburg U-Pb concordia diagram (Fig. 4). The zircon crystals have U contents as high as 2370 ppm (analysis 12.1) and highly variable radiogenic $\mathrm{Pb}$. Zircon crystals with magmatic texture define a cluster at c. $470 \mathrm{Ma}$. This cluster shows marked excess scatter that may originate from loss of radiogenic $\mathrm{Pb}$ (analysis 5.1, 13.1 and 15.1) and inheritance (analysis 3.1), respectively. Omitting these zircon samples, the weighted mean yields a ${ }^{206} \mathrm{~Pb} /{ }^{238} \mathrm{U}$ age of $470 \pm 3 \mathrm{Ma}(\mathrm{MSWD}=0.90 ; \mathrm{n}=$ 11). Two analyses from xenocrystic crystals give apparent ${ }^{206} \mathrm{~Pb} /{ }^{238} \mathrm{U}$ ages of $837 \pm 9 \mathrm{Ma}(1 \sigma$; spot 1.1) and $1995 \pm 22 \mathrm{Ma}(1 \sigma ;$ spot 4.1), respectively. These ages represent minimum ages and suggest the involvement of material derived from an old craton.

The metaporphyroid (P1) belongs to the so-called Feldspat-Blastengneis (Anras/Pustertal) of the Thurntal Complex (Fig. 2b). Zircon crystals from sample P1 are generally euhedral to subhedral. A slight rounding of the edges may reflect a thermal overprint. Most of these zircon grains show complex internal CL structures with rounded or angular cores surrounded by oscillatory-zoned magmatic overgrowth (Fig. 3c, d). The supposedly xenocrystic cores generally show magmatic zoning. Some cores, however, show diffuse and unstructured CL patterns that may result from earlier late-magmatic or metamorphic recrystallization. Resorbtion during intermittent magmatic crystallization of the rim is documented by dissolution surfaces 
intersecting the regular magmatic growth zoning. As the magmatic age of this rock was of primary interest, most analyses were sited in the zoned overgrowths or discrete magmatic grains. For the porphyroid sample P1, seventeen zircon crystals were selected for SHRIMP U-Pb analyses. The data are reported in Table 2 and plotted in a Tera-Wasserburg U-Pb concordia diagram (Fig. 4). Sixteen analyses plot in a group near the concordia and define a mixing line between radiogenic and common $\mathrm{Pb}$ compositions. These data yield a weighted average ${ }^{206} \mathrm{~Pb} /{ }^{238} \mathrm{U}$ age of $477 \pm 4 \mathrm{Ma}(\mathrm{MSWD}=0.61$; Fig. 4). Two analyses were excluded from the calculation of this age as they fully (spot 2.1) or partially (spot 3.1) sampled the inherited core. The core (2.1) has an apparent ${ }^{206} \mathrm{~Pb} /{ }^{238} \mathrm{U}$ age of $606 \pm 10 \mathrm{Ma}(1 \sigma)$. This age is a minimum age. Its relatively large uncertainty is due to the low $\mathrm{U}$ content of this zircon.

\section{Staurolite and kyanite}

Staurolite- and staurolite-kyanite-schist samples were collected near Lake Stierbichl (Fig. 1). The common mineral assemblage is biotite, muscovite/paragonite, chlorite, quartz, plagioclase, staurolite and garnet, with accessory amounts of ilmenite, tourmaline and zircon. Occasionally kyanite occurs in addition to and in similar quantities as staurolite. As in our kyanite-bearing sample (Fig. 2.c) mm-sized poikiloblasts are then intimately intergrown with staurolite. Kyanite and staurolite contain an $\mathrm{s}_{\mathrm{i}}$ of quartz + ilmenite parallelling $\mathrm{s}_{2}$. Staurolite from two samples (ST21 and ST2-2) and kyanite from a third sample were separated using standard mineral processing procedures and selected under the binocular microscope. Material selected for the step-leaching experiments showed no inclusions under the binocular microscope. Back-scattered electron (BSE) images of polished grain-mounts, however, revealed abundant tiny inclusions of quartz, ilmenite, biotite, andesine, and rare zircon. Samples were ground in an agate mortar and then exposed to a series of increasingly stronger acids, comparable to the procedure described by Frei et al. (1995, 1997) and Romer and Franz (1998). In contrast to most earlier studies, we determined not only the $\mathrm{Pb}$ isotopic composition of each leachate, but also their $\mathrm{Pb}$ and $\mathrm{U}$ content. The analyical results are shown in Tables 3 and 4.

The lead isotopic composition of leachates from staurolite sample ST2-1 varies systematically during the leaching procedure (Tables 3 and 4). (1) The $\mathrm{H}_{2} \mathrm{O}$ wash and the $\mathrm{HBr}$ leach are characterized by high ${ }^{207} \mathrm{~Pb} /{ }^{204} \mathrm{~Pb}$ values in comparision with the other fractions. Furthermore, 
the hot $\mathrm{H}_{2} \mathrm{O}$ wash shows distinctly higher ${ }^{208} \mathrm{~Pb} /{ }^{204} \mathrm{~Pb}$ than several of the late leachates. (2) The $\mathrm{HNO}_{3}$ leachate is characterized by radiogenic $\mathrm{Pb}$ that reflects a higher $\mathrm{Th} / \mathrm{U}$ than the other leachates (Fig. 5), with the possible exception of the $\mathrm{HBr}$ leachate. (3) The various $\mathrm{HCl}$ and $\mathrm{HF}$ leachates show little radiogenic $\mathrm{Pb}$ that falls in the ${ }^{206} \mathrm{~Pb} /{ }^{204} \mathrm{~Pb}-{ }^{208} \mathrm{~Pb} /{ }^{204} \mathrm{~Pb}$ diagram on a linear trend (Fig. 5), i.e., were leached from sections that had a similar initial $\mathrm{Pb}$ isotopic composition and a common $\mathrm{Th} / \mathrm{U}$. The contrasting isotopic signatures of the various leachates indicate that $\mathrm{Pb}$ was released from distinct phases of contrasting $\mathrm{Th} / \mathrm{U}$ and $\mathrm{Pb} / \mathrm{U}$. Furthermore, more than $75 \%$ of the bulk $\mathrm{Pb}$ was released during three leaching steps, i.e., the hot $\mathrm{H}_{2} \mathrm{O}$ wash, the $\mathrm{HNO}_{3}$ leach, and the $20 \% \mathrm{HF}$ leach. The distribution of Pb-release and the distinct isotopic signature of the various solutions indicates that $\mathrm{Pb}$ was mobilized from different locations and different inclusions within staurolite. The $\mathrm{HNO}_{3}, \mathrm{HCl}$, and $\mathrm{HF}$ leachates fall in the ${ }^{206} \mathrm{~Pb} /{ }^{204} \mathrm{~Pb}-$ ${ }^{207} \mathrm{~Pb} /{ }^{204} \mathrm{~Pb}$ diagram on a common linear trend whose slope $(0.05109)$ corresponds to an age of $\mathrm{c}$. $245 \mathrm{Ma}$, provided the data reflect undisturbed lead growth starting from the same initial $\mathrm{Pb}$ isotopic composition. The slope of this line, however, is dominated entirely by the $\mathrm{HNO}_{3}$ leach.

The lead isotope data of the various leachates of staurolite from sample ST2-2 (Table 3) define in the ${ }^{206} \mathrm{~Pb} /{ }^{204} \mathrm{~Pb}-{ }^{208} \mathrm{~Pb} /{ }^{204} \mathrm{~Pb}$ diagram two contrasting trends (Fig. 5) that can be interpreted to reflect three different end-members: (1) non-radiogenic common $\mathrm{Pb}$, (2) radiogenic $\mathrm{Pb}$ with low $\mathrm{Th} / \mathrm{U}$, and (3) radiogenic $\mathrm{Pb}$ with high $\mathrm{Th} / \mathrm{U}$. Samples with a low inferred $\mathrm{Th} / \mathrm{U}$ define in the ${ }^{206} \mathrm{~Pb} /{ }^{204} \mathrm{~Pb}-{ }^{207} \mathrm{~Pb} /{ }^{204} \mathrm{~Pb}$ diagram a steeper line, i.e., define an older age, than the samples with a high-Th/U (Fig. 5). The contrasting isotopic signature is linked to inclusions rather than to contrasting domains in the staurolite, which would have to be characterized not only by different $\mathrm{Th} / \mathrm{U}$, but also by contrasting leaching behavior. For instance, the least radiogenic $\mathrm{Pb}$ in both staurolite samples is found for the $20 \% \mathrm{HF}$ leachate, which comprises about 20 to $30 \%$ of $\mathrm{Pb}_{\text {total }}$ (Table 4). Since feldspar contains high $\mathrm{Pb}$ contents and incorporates no or very little $\mathrm{U}$, this non-radiogenic $\mathrm{Pb}$ may reflect the selective decomposition of feldspar inclusions and intergrowths that are observed on BSE images. The isotopic contrast among different leaching steps is likely to reflect the preferential dissolution of micro-inclusions rather than the dissolution of chemically contrasting staurolite domains. The U-Pb systematics of staurolite sample ST2-2 represents a mixture of $\mathrm{Pb}$ derived from many different sources (minerals), the $\mathrm{Pb}$ isotopic composition of the various leaching steps being dominated by different minerals. 
Because individual leaching steps may include $\mathrm{Pb}$ released from several different phases, each lead line represents a rotated mixing line whose slope does not necessarily allow to derive an accurate age. The lead line with steepest ${ }^{207} \mathrm{~Pb} /{ }^{206} \mathrm{~Pb}$ slope in the ${ }^{206} \mathrm{~Pb} /{ }^{204} \mathrm{~Pb}-{ }^{207} \mathrm{~Pb} /{ }^{204} \mathrm{~Pb}$ diagram constrains a minimum age of $465 \mathrm{Ma}$. This lead line is defined by samples $(14,15$, and 16) with low ${ }^{208} \mathrm{~Pb} /{ }^{204} \mathrm{~Pb}$ values. These samples define also in the ${ }^{206} \mathrm{~Pb} /{ }^{204} \mathrm{~Pb}-{ }^{208} \mathrm{~Pb} /{ }^{204} \mathrm{~Pb}$ diagram (Fig. 5) a straight line, whose ${ }^{206} \mathrm{~Pb} /{ }^{208} \mathrm{~Pb}$ slope corresponds to a $\mathrm{Th} / \mathrm{U}_{\text {at }}$ of c. 0.06 . Such low $\mathrm{Th} / \mathrm{U}_{\text {at }}$ values are known for zircon from highly evolved magmatic and fluid-dominated metamorphic systems (e.g., Heaman et al. 1990; Kalt et al. 2000). A second lead line is dominated by the $\mathrm{HNO}_{3}$ leach. This line is flatter in the ${ }^{206} \mathrm{~Pb} /{ }^{204} \mathrm{~Pb}-{ }^{207} \mathrm{~Pb} /{ }^{204} \mathrm{~Pb}$ diagram, which corresponds to a younger apparent age of $248 \mathrm{Ma}$. This lead line suggests a $\mathrm{Th} / \mathrm{U}_{\mathrm{at}}$ of c. 8 for the $\mathrm{Pb}$-source dissolved during the $\mathrm{HNO}_{3}$ leaching-step. Since the $\mathrm{HNO}_{3}$-leachate carries more than $50 \%$ of the staurolite- $\mathrm{Pb}$ (left after $\mathrm{H}_{2} \mathrm{O}$-wash, Table 3 ) and has distinctly higher contents of thorogenic $\mathrm{Pb}$ than the other leachates, it is likely that the $\mathrm{Pb}$ of these fractions does not represent staurolite $\mathrm{Pb}$, but the $\mathrm{Pb}$ of inclusions in staurolite (see also Frei et al. 1995, 1997). A possible candidate for such inclusions is ilmenite with high Th/U (e.g., Mahood and Hildreth 1983; Lemarchand et al. 1987). It is important to note that the $\mathrm{Pb}$ lines primarily constrain the age of the inclusions, not the staurolite. The age of the staurolite porphyroblast is only constrained by the textural and genetic relation between staurolite and the dated inclusions (Fig. 2c).

The $\mathrm{Pb}$ budget of the analyzed kyanite is dominated by two leaching steps. The $\mathrm{HBr}$ and $20 \%$ $\mathrm{HF}$ leaching steps released $90 \%$ of the available lead. This $\mathrm{Pb}$ is characterized by an unradiogenic composition (Table 3). The remaining leachates have more radiogenic $\mathrm{Pb}$ isotopic compositions. The most radiogenic one was observed for the wash in hot $\mathrm{H}_{2} \mathrm{O}$ and, thus, may represent losely attached $\mathrm{Pb}$ located in fractures and on crystal surfaces. Since the readily mobilized $\mathrm{Pb}$ contained in the $\mathrm{H}_{2} \mathrm{O}$ wash may have been multiply redistributed or scavenged from fluids, it is not considered for the dating of the kyanite sample. All leachates with radiogenic lead are characterized by very small amounts of $\mathrm{Pb}$ (Table 4). The kyanite $\mathrm{Pb}$ data scatter in the ${ }^{206} \mathrm{~Pb} /{ }^{204} \mathrm{~Pb}-{ }^{207} \mathrm{~Pb} /{ }^{204} \mathrm{~Pb}$ and ${ }^{206} \mathrm{~Pb} /{ }^{204} \mathrm{~Pb}-{ }^{208} \mathrm{~Pb} /{ }^{204} \mathrm{~Pb}$ diagrams about linear trends, with the exception of two samples that have slightly enhanced ${ }^{207} \mathrm{~Pb} /{ }^{204} \mathrm{~Pb}$ values and distinctly higher $\mathrm{Th} / \mathrm{U}$ and ${ }^{208} \mathrm{~Pb} /{ }^{204} \mathrm{~Pb}$ values (Fig. 5) than the other samples. These two samples are the $\mathrm{HNO}_{3}$ and the $\mathrm{HCl}$ leachate (Table 4). The remaining leachates indicate $\mathrm{Th} / \mathrm{U}_{\mathrm{at}}<<0.1$. The leaching behavior of kyanite indicates that little $\mathrm{Pb}$ enters the crystal structure of kyanite. 
Instead, is is hosted in fluid inclusions or readily dissolved mineral inclusions. The contrasting isotopic signature of the $\mathrm{HNO}_{3}$ and $\mathrm{HCl}$ leachates may reflect the preferential and selective dissolution of inclusions within kyanite.

Step-leaching may selectively release $\mathrm{U}$ and $\mathrm{Pb}$ from inclusions or from chemically distinct segments of the analyzed minerals. Especially if most of the $U$ is hosted in small inclusions, the step leaching procedure may result in a fractionation between $\mathrm{U}$ and $\mathrm{Pb}$ and the release of $\mathrm{Pb}$ with an anomalous isotopic composition. The cause for this non-ideal behavior is $\alpha$-recoil. Each $\alpha$-decay displaces the daughter isotope by some 20 to $30 \mathrm{~nm}$ from the site of its parent (e.g., Matzke 1982; Ziegler et al. 1985). The radiogenic isotopes ${ }^{206} \mathrm{~Pb},{ }^{207} \mathrm{~Pb}$, and ${ }^{208} \mathrm{~Pb}$, therefore, have been displaced by 8,7 , and $6 \alpha$-recoils, respectively. For samples that show a heterogeneous distribution of the parent element on the small scale (e.g., micro-inclusions), $\alpha-$ recoil results in contrasting distributions of parent and daughter isotopes (cf. Romer and Thomas 2005). An U- and Th-rich inclusion eventually shows a deficit in $\mathrm{Pb}$ (as more $\mathrm{Pb}$ is lost to the $\mathrm{U}$ and Th-poor host than $\mathrm{Pb}$ is received from the host). In contrast, the $\mathrm{U}$ - and Th-poor host shows $\mathrm{Pb}$-excess. Whereas most dating approaches sample sufficiently large volumes to average effects of daughter redistribution by $\alpha$-recoil, the step-leaching procedure selectively dissolves micro inclusions (e.g., Romer 2003; Romer and Thomas 2005). This effect, which may be superimposed by the preferential dissolution of domains with a higher density of recoil-induced lattice damage (i.e., the U and Th rich domains, e.g., Mattinson 1994; Mattinson et al. 1996), may cause the fractionation of parent and daughter. This process explains the spurious ${ }^{206} \mathrm{~Pb} /{ }^{238} \mathrm{U}$ ages for the various leaching steps (Table 3). The weighted average of ${ }^{206} \mathrm{~Pb} /{ }^{238} \mathrm{U}$ ages falls for all samples in the range 218 to $281 \mathrm{Ma}$. Redistribution of radiogenic $\mathrm{Pb}$ may affect the various $\mathrm{Pb}$ isotopes differently as radiogenic ${ }^{206} \mathrm{~Pb},{ }^{207} \mathrm{~Pb}$, and ${ }^{208} \mathrm{~Pb}$ have been displaced by a different number of recoils. Step-wise leaching of heterogeneous minerals, thus, may yield nonrepresentative ratios among the radiogenic $\mathrm{Pb}$ isotopes (for examples see the experiments on zircon by Mattinson et al. [1996], Corfu [2000], and Davis and Krogh [2000]). Although this kind of recoil-related isotopic fractionation is not likely to reach a large magnitude, there may be an age offset of a few tens of million years for very small inclusions. In the light of these uncertainties, the results of the leaching experiments for staurolite and kyanite are summarized as follows: (i) staurolite contains inclusions of Ordovician or older zircon. It is unclear whether this zircon is related to a magmatic or metamorphic event. (ii) Ilmenite inclusions reflect a 
Variscan event. (iii) Most $U$ is hosted in inclusions, there is essentially no $U$ in the lattice of staurolite (and possibly kyanite). Thus, U-Pb age data derived from staurolite (and kyanite) are likely to date the inclusions rather than the host.

\section{Ar-Ar-hornblende}

Sample OD 21 is an amphibolite from the MPU to the south of the DAV and contains hornblende, plagioclase, garnet, and chlorite and accessory quartz, clinozoisite, sphene, zircon, and opaque minerals. The investigated amphiboles are mineralogically heterogeneous. They were step-heated with 13 - 14 fractions extracted from each sample. None of the samples shows a plateau that is defined by three or more fractions constituting $>50 \%$ gas release and falling within 2 standard deviations of the mean (Fig. 6). The gas released at the lowest temperatures, corresponding to about $2 \%$ of the total gas release, is characterized by a low $\mathrm{Ca} / \mathrm{K}$, yields a poorly defined age of $\sim 190 \mathrm{Ma}$, and may reflect secondary biotite on cleavage planes (e.g., Sisson and Onstott 1986). The second type of Ar, accounting for $\sim 86 \%$ of the total Ar release, is characterized by a fairly homogeneous $\mathrm{Ca} / \mathrm{K}$ value of 28 and yields a scattered pattern averaging around $360 \mathrm{Ma}$. The last Ar released is associated with a high $\mathrm{Ca} / \mathrm{K}$ phase, possibly pyroxene exsolutions, that yields anomalous ages $>500 \mathrm{Ma}$. The heterogeneous nature of these samples does not allow the determination of ages. The bulk of the released Ar, however, suggests that the amphiboles may have formed during the Variscan or an older event.

\section{Discussion}

\section{Age of pre-Variscan arc}

During the Cambro-Ordovician evolution of the Gondwana-derived terranes, magmatic rocks play an important role. Granitoids ranging in age from 494 to $420 \mathrm{Ma}$ were discriminated according to Maniar and Piccoli (1989) into (i) Cambrian plagiogranites related with the formation of oceanic crust, (ii) alkaline granites representing rifting of thickened crust 
contemporaneous to the opening of an ocean, and (iii) calc-alkaline meta-aluminous granites that seem to have formed in a Cambro-Ordovician active margin setting, whereas (iv) younger ( \pm 450 Ma) less calc-alkaline peraluminous granitoids (collisional granitoids) that carry the characteristics of a late- to post-orogenic evolution. Heinisch (1981), Schulz (1997), and von Raumer (1998) used the granitoids to subdivide the pre-Variscan units into a pre-Ordovician and post-Ordovician basement (Neubauer 2002; von Raumer et al. 2002, 2003).

Orthogneisses of the MPU and AMU to the south of the Tauern Window to belong to two groups. The first group belongs to peraluminous syncollisional S-type granitoids (e.g., Antholz, Leisach, and Sand in Taufers). In the second group, major element chemistry and the presence of two feldspars suggest that the original granite is derived from a water undersaturated partial melting of calc-alkaline metagraywacke in the lower crust. Orthogneisses of Gsies type represent former peraluminous to metaluminous high K-granitoids whose magmatic source could have been lower crustal rocks of a volcanic arc association.

Existing age information of both groups, felsic plutonic and volcanic rocks, yield ages at 480 - $450 \mathrm{Ma}$, whereas mafic rocks are grouped into sequences of $590 \mathrm{Ma}$ (eclogitic amphibolites) and 550 - $530 \mathrm{Ma}$ (hornblende-plagioclase gneisses; Schulz and Bombach 2003).

The Barenle orthogneiss (BS3; weakly peraluminous CAG) is intercalated with the Schober Group eclogitic amphibolites and hornblende plagioclase gneisses as well as metapelites and paragneisses. Detrital zircon grains give ages around 2.0 Ga. Such data are comparable to Paleoproterozoic ages of inherited cores were found by Gebauer and Grünfelder (1977), Thöni (1999), Neubauer et al. (2002), Doman (2002), and von Raumer et al. (2003). These Svecofennian-Birimian-Amazonian and older ages for inherited cores suggest that the "Altkristallin" is part of the Avalonia superterrane that was derived from the NW margin of Gondwana, i.e., present-day northern South America. A weighted mean ${ }^{206} \mathrm{~Pb} /{ }^{238} \mathrm{U}$ age of $470 \pm$ $3 \mathrm{Ma}$ for sample BS3 is interpreted as the crystallization age. The Schober Group eclogitic amphibolites and related rocks (Prijakt Subgroup) pose particular interpretational problems because various units of the association provide different zircon ages between 590 and $460 \mathrm{Ma}$, all of them taken to result from crystallization events of the different protoliths (Schulz and Bombach 2003). The eclogite metamorphism - post $590 \mathrm{Ma}$ according to these authors - would have to predate the crystallisation age of the non-eclogitic Barrenle orthogneiss (BS3) of our study. The intimate interleaving of both rock units observed in the field is taken to indicate a 
juxtaposition at an early stage. The field and microstructural observations combined with the geochemical signature could support a scenario of a network of calc-alkaline granitoid dykes intruding a much older eclogitic basement in an active continental margin setting. In accordance with the interpretation by Schulz and Bombach (2003) the intrusion may represent a syncollisional event in the 550-470 Ma subduction-accretion-collision cycle. At any rate, juxtaposition of eclogite and granitoid must have taken place before or latest during the pervasive amphibolite-grade deformation affecting both. So far, structural observations and carboniferous mica ages represent the only evidence for Variscan metamorphism to the south of the Defereggen-Antholz-Vals (DAV) Line.

The age spectra of the orthogneisses of the AMU and MPU (Schulz \& Bombach, 2003) seem to be slightly younger than the metarhyolites (P1) of the Thurntaler Complex (Fig.1). The Thurntaler phyllite complex overlies the MPU along a pre-Alpine foliation-parallel contact (Heinisch \& Schmidt 1984; Schulz 1991; Kreutzer 1992). The metarhyolites (porphyroids) from the Thurntaler Complex of this study are characterized by a weighted mean ${ }^{206} \mathrm{~Pb} /{ }^{238} \mathrm{U}$ age of 477 $\pm 4 \mathrm{Ma}$ (Fig. 4) with some inherited older cores pointing to around $600 \mathrm{Ma}$. Concordant U-Pb ages of $479 \pm 8 \mathrm{Ma}$ and $485 \pm 8 \mathrm{Ma}$ from the Southern Alps Comelico porphyroid zircon population (Meli and Klötzli 2001) are quite similar to our data. Since Kreutzer (1992) has shown the mafic metavolcanics of the Thurntal Complex to represent within-plate metatholeiites, some of them sub-alkaline, we concur with this interpretation of the bimodal association as indicating an intra-plate intracontinental extensional setting where the silicic melts were mobilized from older calc-alkaline source rocks. Up to now there is no age determination of the mafic members of the bimodal association. If felsic and mafic rocks are coeval, an extensional tectonic setting was established already for the Lower Ordovician. In contrast if the association is purely tectonic, the extension must be younger. Moreover, the REE pattern of the porphyroids matches the data from the orthogneisses very well and demonstrate the geochemical similarity of both rock groups as had already been stated by Heinisch (1981) and Heinisch and Schmidt (1982). 


\section{Age of metamorphism}

The age of the metamorphism in the Altkristallin (AMU and MPU) is still a matter of discussion. For instance, it is often stressed that foliated amphibolite xenoliths within Ordovician felsic orthogneisses within the Western Altkristallin described by Peccerillo et al. (1979), indicate that mafic rocks were already deformed at c. 470 Ma. In contrast, Sassi and Zanfrerari (1972) proposed a "Caledonian" amphibolite facies metamorphism while others (e.g., Cliff 1980; Bellieni and Visona 1981; Stöckhert 1982, 1985; Hoke 1990) suggested that the amphibolite facies mineral assemblages in the MPU and AMU are locally younger than the main foliation S2 of the metapsammopelites. Since S2 is parallel to a corresponding foliation in the Ordovician granitoids, this implies that metamorphism post-dates the felsic intrusion.

Microstructural evidence shows that staurolite and garnet-1 growth (Fig. 2c) occurred late to post kinematic with respect to D2 and that staurolite surrounded by crenulated (F3) matrix may locally enclose internal foliations with small garnet. Thus, the age of staurolite would constrain the age of peak metamorphism (Schulz et al. 2001). The $\mathrm{Pb}-\mathrm{Pb}$ and U-Pb systematics of leachates from staurolite and kyanite from these metapelites is bound to inclusions like ilmenite formed during metamorphism. The Variscan age of these inclusions puts a maximum age for staurolite and kyanite growth and precludes a pre-Variscan age of the metamorphism of schists.

\section{Conclusion}

We present two SHRIMP U-Pb-analyses of zircon grains from metamagmatic rocks of the Altkristallin S of the Tauern Window. The data are used to test and supplement existing age concepts of the igneous component in a pre-Alpine basement complex of which age information so far is based on $\mathrm{Pb}-\mathrm{Pb}$-evaporation and multigrain zircon studies apart from older $\mathrm{Rb} / \mathrm{Sr}$ whole rock data. In particular an age of 470+-3 Ma dates the crystallization of a calc-alkaline metagranite intruding the arc-related metamafic sequence of the Prijakt eclogitic amphibolites and hornblende-plagiocalse gneiss of 477+-4 Ma dates the extrusion of metarhyolites in the bimodal association with intraplate alkali-basalts of the Thurntaler Complex. These precise SHRIMP ages underline the overlap in time of subduction-collision-related magmatism with the 
igneous activity in an extensional intra-plate setting that had been indicated before for much of the Early-Paleozoic Austroalpine basement.

$\mathrm{U}-\mathrm{Pb}$-isotope analysis by step-wise leaching of staurolite and kyanite from medium grade paragneisses of the same complex was used in an attempt to more closely constrain the age(s) of metamorphism of this polymetamorphic assemblage. The significance of the minimum age of $465 \mathrm{Ma}$ for zircon enclosed in staurolite is not clear. Zircon could have formed during metamorphism in which case the zircon age would provide evidence for a Caledonian metamorphism of the paragneisses. Alternatively, if the zircon in staurolite represents detrital zircon in the pararocks, the zircon age would constrain the age of the sediment precursor, but leave the age of sedimentation and subsequent metamorphism little constrained. Last, a medium $\mathrm{P}$ event leads to crystallization of staurolite-kyanite assemblages in some parts of the paragneiss. Ilmenite that crystallized during this metamorphism and forms inclusions in staurolite reflect a Variscan minimum age ranging between 218-281 Ma. This clearly assigns it to the Variscan collisional cycle finally amalgamating Gondwana and Laurasia, an inference that so far was based solely on structural and regional geologic considerations. Based on structural considerations, this age also constrains the metamorphism of the Thurntaler Complex.

\section{Acknowledgments}

We thank C. Schulz (GFZ Potsdam) for support in the laboratory. S.S. thanks Rich Armstrong and Paul Layer for help with the U-Pb SHRIMP and the Ar-Ar age determination, respectively. B. Schulz (Freiberg) is thanked for the open and unreserved discussions during long-term joint field work. We greatly appreciated constructive reviews by B. Schulz (Freiberg) and Xxxxx

\section{Figure Captions}

Fig. 1. Geological units in the basement to the south of the Tauern Window, Eastern Alps (after ScHULZ et al., 2001). Encircled numbers 1-4 refer to sampling locations of the presented isotope data. 1 Sample BS1 (Lake Barenle orthogneiss); 2 Sample P1 (Anras metaporphyroid); 3 Samples ST2-1 and ST2-2 (Lake Stierbichl staurolite- and staurolite-kyanite-schists); 4 Sample OD21 (amphibolite, MPU); A orthogneiss of Antholz; AB Austroalpine basement; AMU 
metapelite-amphibolite-marble unit (Durreck Muscoviteschist and Northern Defereggen Petzek Group); bg biotite gneisses; CT orthogneiss of Sand i. T. (Campo Tures); CN metabasites of Corda Nera; DAV Defereggen-Antholz Vals line; ecl amphibolized eclogites of the Schober Group (Prijakt Subgroup); G orthogneiss of Gsies (Casies); gm garnet-muscovite schists of the AMU; H Hochgrabe orthogneiss; KV Kalkstein-Vallagra line; L tonalite of Lienz; Le orthogneiss of Leisach; LS Lasörling series of the AMU with augengneiss series and hornblendeplagioclase series (Rotenkogel Subgroup); MPU metapsammopelitic unit (Defereggen Group); MZ Matreier Zone; NCA Northern Calcareous Alps; ND Northern Drauzug fault; P Penninic unit; PA paleozoic of the Greywacke Zone; PL Periadriatic Lineament; pm phyllitic mica schists of the MPU; R Rieserferner tonalite; S orthogneiss of Staller Sattel; SA South-Alpine; T PermoTrias and Trias; TC Thurntaler Complex (Thurntaler Phyllite Group); U Late-Variscan pegmatites of Uttenheim (Villa Ottone); Z Zinsnock tonatite; Zu metabasites of Moldaber, Lämperer and Gr. Zunig.

Fig. 2. Microstructures and petrography of selected samples; BSE images.

a) Sample BS3; orthogneiss, from one of a number of bands intercalated in the eclogitic amphibolite association, Barenle cirque, Prijakt, Hochschober; aln = allanite, $\mathrm{kfs}=$ microcline, $\mathrm{plg}=$ oligoclase, $\mathrm{qz}=$ quartz, $\mathrm{grt}=$ almandine, $\mathrm{czo}=$ clinozoisite, mus $=$ white mica, bio $=$ biotite; frequent accessories not shown: apatite, zircon; macroscopic foliation $\mathrm{s}_{1}$ results from ribbons and lenses of two-feldspar and quartz polycrystals with biotite; $s_{1}$ is cut at an acute angle by a younger foliation of biotite, clinozoisite, and muscovite.

b) Sample P1 ; MetaPorphyroid, Thurntaler Complex, forestry road cut ca. $1 \mathrm{~km} \mathrm{~N}$ of the church of Anras/Pustertal, so-called "Feldspat-Blastengneis", a metarhyolite with particularly coarse feldspars, consisting of ca. $30 \% \mathrm{vol}$ of mm-sized feldspar clasts dispersed with little dimensional orientation in a finely laminated dark matrix; image shows detail from the margin of a feldspar clast, a phenocryst ghost of albite with inclusions of phengite, clinozoisite, small zircon, surrounded by a foliated matrix of recrystallized quartz, phengitic muscovite, chlorite, clinozoisite, albite plus accessory sphene, ilmenite, Ti-magnetite, and zircon.

c) Sample ST2-2/1611. Two-mica schist from the shores of Stierbichl Lake, Eastern Defereggen Alps. st $=$ staurolite with quartz and ilmenite inclusions, $\mathrm{Al}_{2} \mathrm{SiO}_{5}=$ kyanite with staurolite, ilmenite, and quartz inclusions, bio = biotite, $\mathrm{Mn}$-alm $=$ Mn-rich almandine, $\mathrm{Na}$ mus $=$ 
paragonitic muscovite, $\mathrm{qz}=$ quartz, $\mathrm{ilm}=$ ilmenite, $\mathrm{czo}=$ clinozoisite. Kyanite as well as staurolite contain an $\mathrm{s}_{\mathrm{i}}$ (internal foliation) of quartz and ilmenite parallelling $\mathrm{s}_{2}$. Kyanite embraces staurolite fragments. Their close intergrowth may reflect a staurolite consuming reaction. Small crenulation folds in mica-rich-zones of this rock type commonly show staurolite occupying the fold apices. Staurolite is typically slightly rotated and traversed by a network of irregular fractures filled with a fine felt of white mica and chlorite corresponding to the $\mathrm{s}_{4}$ extensional crenulation cleavage. Staurolite growth is therefore very late- to post-kinematic with respect to D2 but pre-dating D4 $\boldsymbol{d}$ ) Sample OG 21, garnet-hornblendegneiss with hornblende and garnet in a matrix of quartz, albite, locally chlorite, and phengitic muscovite.

Fig.3. SEM cathodoluminescence images showing internal growth patterns of typical zircons. ab) Sample BS3, Barenle orthogneiss, Prijakt Area; $\boldsymbol{c}$-d) Sample P1, Anras metaporphyroid, Thurntal Complex; Scalebars $30 \mu \mathrm{m}$.

Fig.4. SHRIMP data for zircons from samples BS3 and P1 plotted on a Tera-Wasserburg U-Pb concordia diagram. Note that the data are plotted uncorrected for common $\mathrm{Pb}$.

Fig. 5. ${ }^{206} \mathrm{~Pb} /{ }^{204} \mathrm{~Pb}-{ }^{208} \mathrm{~Pb} /{ }^{204} \mathrm{~Pb}$ and ${ }^{207} \mathrm{~Pb} /{ }^{204} \mathrm{~Pb}-{ }^{206} \mathrm{~Pb} /{ }^{204} \mathrm{~Pb}$ diagrams for staurolite and kyanite.

Fig. $6 .{ }^{40} \mathrm{Ar} /{ }^{39} \mathrm{Ar}$ analysis for the amphibolite OD21 were performed at Geochronology laboratory at University of Alaska Fairbanks (for details it is referred to Layer et al. 1987).

\section{References}

Bellieni G, Visona D (1981) Metamorphic evolution of the Austroalpine schists outcropping between the intrusive masses of Vedretti di Ries (Rieserferner) and Cima di Vila (Zinsnock) (Eastern Alps, Italy). N Jb Geol Paläont Mh 76: 586-602

Borsi S, Del Moro A, Sassi FP, Zirpoli G (1973) Metamorphic evolution of the Austridic rocks to the South of the Tauern Window (Eastern Alps). Radiometric amd geopetrologic data. Mem Soc Ital 12: 549-571 
Borsi S, Del Moro A, Sassi FP, Zanfrerrari A, Zirpoli G (1978) New geopetrologic and radiometric data on the Alpine history of the Austridic continental margin south of the Tauern Window. Mem. Inst. Geol. Mineral. Univ Padova 32: 1-17

Chen F, Hegener E, Todt W (2000) Zircon ages and Nd isotopic and chemical composition of orthogneisses from the Black Forest, Germany: evidence for a Cambrian magmatic arc. Int $\mathrm{J}$ Earth Sci 88: 791-802.

Clar E (1972) Ein Beitrag zur Geologie der Sachobergruppe bei Lienz in Tirol. Mitt Natw Ver Steiermark 63: 345-440.

Cliff RA (1980) U-Pb isotopic evidence from zircons for lower Paleozoic tectonic activity in the Austroalpine nappe, the eastern Alps. Contrib Mineral Petrol 71: 238-288

Compston W, Williams IS, Kirschvink JL, ZhangZ, Ma G (1992). Zircon U-Pb ages for the early Cambrian time scale. J Geol Soc Lond 149:171-184

Corfu F (2000) Extraction of $\mathrm{Pb}$ with artificially too-old ages during stepwise dissolution experiments on Archean zircon. Lithos 53: 279-291

Cumming GL, Richards JR (1975) Ore lead isotope ratios in a continuously changing Earth. Earth Planet Sci Lett 28: 155-175

Dal Piaz G (1934) Studi geologica sull'Alto Adige e regione limitrofe. Mem Ist Geol Univ Padova 10: 1-238

Davis DW, Krogh TE (2000) Preferential dissolution of ${ }^{234} \mathrm{U}$ and radiogenic $\mathrm{Pb}$ from alpharecoil-damaged lattice sites in zircon; implications for thermal histories and $\mathrm{Pb}$ isotopic fractionation in the near surface environment. Chem Geol 172: 41-58

Doman D (2002) U/Pb Datierungen an Orthogneisen im ostalpinen Altkristallin südlich des Tauernfensters. Unpubl Diploma Thesis, Univ Göttingen, 87pp

Foden J, Sandiford M, Dougherty-Page J, Willimas I (1999) Geochemistry and geochronology of the Rathjen Gneiss: implication for the early tectonic evolution of the Delameriamn Orogen. Austral J Earth Sci 46: 377-389

Frei R, Biino GG, Prospert C (1995) Dating a Variscan pressure-temperature loop with staurolite. Geology 23: 1095-1098

Frei R, Villa IM, Nägler ThF, Kramers JD, Przybylowicz WJ, Prozesky VM, Hofmann BA, Kamber BS (1997) Single mineral dating by the Pb-Pb step-leaching method: Assessing the mechanisms. Geochim Cosmochim Acta 61: 393-414 
Gebauer D, Grünfelder M (1977) U-Pb systematics of detrital zircons from some unmetamorphosed to slightly metamorphosed sediments of Central Europe. Contrib Mineral Petrol 65: 29-37

Gerstenberger H, Haase G (1997) A highly effective emitter substance for mass spectrometric $\mathrm{Pb}$ isotope ratio determinations. Chem Geol 136: 309 - 312

Hammerschmidt K (1981) Isotopengeologische Untersuchungen am Augengneis vom Typ Campo Tures bei Rain in Taufers, Südtirol. Mem Ist Geol Min Univ Padova 34: 273-300

Heaman LM, Bowins R, Crocked J (1990) The chemical composition of igneous zircon suites: Implications for geochemical tracer studies. Geochim Cosmochim Acta 54: 1597-1607

Heinisch H (1981) Zum ordovitischen Porphyroid-Vilkanismus der Ost- und Südalpen. Jb Geol B-A 124: 1-109

Heinisch H, Schmidt K (1976) Zur kaledonischen Orogenese in den Ostalpen. Geol Rundsch $65: 459-482$

Heinisch H, Schmidt K (1982) Zur Genese der Augengneise im Altkristallin der Ostalpen. N Jb Geol Paläont Mh 4:211-239

Heinisch H, Schmidt K (1984) Zur Geologie des Thurntaler Quarzphyllits und des Altkristallin südlich des Tauernfensters (Ostalpen, Südtirol). Geol Rundsch 73: 113-129

Hoke L (1990) The Altkristallin of the Kreuzeck Mountains, SE Tauern Window, Eastern Alps; basement crust in a convergent plate boundary zone. Jb Geol B-A 133:5-87

Jaffey AH, Flynn KF, Glendenin LE, Bentley WC, Essling AM (1971) Precision measurement of half-lives and specific activities of ${ }^{235} \mathrm{U}$ and ${ }^{238} \mathrm{U}$. Phys Rev C4: 1889 - 1906

Kalt A, Kober B, Pidgeon RT (2000) Further time constraints on Variscan high-pressure metamorphism in the Schwarzwald (Germany). Eur J Mineral 12 (Suppl 1): 91

Klötzli U (1995) Geochronologische Untersuchungen an Metagranitoiden im ostalpinen Altkristallin W und S des Tauernfensters. In: Geologische B A Wien (Eds): Arbeitstagung Lienz 1995: 95-07.

Kreutzer S (1992) Zur Geologie des östlichen Thurtaler Quarzphyllitkomplexes und seiner tektonischen Einbindung in das Ostalpin der südöstlichen Defregegr Alpen. Osttitol. Unpubl PhD Thesis, RWTH Aachen

Krol, W (1974) Geologisch-lagerstättenkundliche Untersuchungen im Gebiet nördlich von Sillian (Osttirol/Österreich. Unpubl PhD thesis, University München 
Layer PW, Hall CM, York D (1987). The derivation of ${ }^{40} \mathrm{Ar} /{ }^{39} \mathrm{Ar}$ age spectra of single grains of hornblende and biotite by laser step heating. Geophys Res Lett 14:757-760

LeBas M J, LeMaittre R W, Streckeisen A, Zanetti B (1986) A chemical classification of volcanic rocks based on the total alkali-silica duiagram. J Petrol 27:745-750

Lemarchand F, Villemant B, Calas G (1987) Trace element distribution coefficients in alkaline series. Geochim Cosmochim Acta 51: 1071-1081

Loeschke J (1989) Lower Palaeozoic volcanism of the Eastern Alps and its geodynamic implication. Geol Rundsch 78: 566-616

Loeschke J, Heinisch H (1993) Palaeozoic volcanismof the Eastern Alps and its palaeotectonic significance. In: von Raumer J, Neubauer F (eds). The pre-Mesozoic geology in the Alps. Springer, Berlin Heidelberg New York, pp 441 - 455

Mahood GA, Hildreth W (1983) Large partition coefficients for trace elements in high silica rhyolites. Geochim Cosmochim Acta 47: 11-30

Manhès G, Minster JF, Allègre CJ (1978) Comparative uranium-thorium-lead and rubidiumstrontium study of the Saint Séverin amphoterite: consequences for early solar system chronology. Earth Planet Sci Lett 39: 14-24

Maniar PD, Piccoli PM (1989) Tectonic discrimination of granitoids. Geol Soc Am Bull 101: 635-643

Mattinson JM (1994) A study of complex discordance in zircons using step-wise dissolution techniques. Contrib Mineral Petrol 116: 117-129

Mattinson JM, Gaubard CM, Parkinson DL, McLelland WC (1996) U-Pb reverse discordance in zircons: the role of fine-scale oscillatory zoning and sub-microscopic transport of $\mathrm{Pb}$. Am Geophys Union Geophys Monogr 95: 355-370

Matzke H (1982) Radiation damage in crystalline insulators, oxides and ceramic nuclear fuels. Rad Effects 64: 3-33

Meli S, Klötzli US (2001) Evidence for Lower Palaeozoic magmatism in the Eastern Southalpine basement: zircon geochronology from Comelico porphyroids. Schweiz Mineral Petrogr Mitt 81: $147-157$

Neubauer F (2002) Evolution of late Neoproterozoic to early Paleozoic tectonic elements in Central and Southeast European Alpine mountain belts:review and synthesis. Tectonophysics 352:87-103 
Neubauer F, Sassi FP (1993) The Austroalpine quartzphyllites and related Palaeozoic Formations. In: von Raumer J, Neubauer F (eds). The pre-Mesozoic geology in the Alps. Springer, Berlin Heidelberg New York, pp 423-439

Neubauer F, Frisch W, Hansen B (2002) Early Palaeozoic tectonothermal events in basement complexes of the eastern Greywacke Zone (Eastern Alps): evidence from U-Pb zircon data. Int J Earth Sci 91:775-786

Paces JB Miller JD (1989) Precise U-Pb ages of Duluth Complex and related mafic intrusions, Northeast Minnesota: geochronological insights to physical, petrogenic, paleomagnetic and tectonomagmatic processes associated with 1.1 Ga midcontinent rift system. J Geophys Res 98B:13997-14013

Pearce JA, Harris NBW, Tindle AG (1984) Trace element discrimination diagrams for the tectonic interpretation of granitic rocks. J Petrol 25:956-983

Peccerillo A, Poli G, Sassi FP, Zipoli G, Mezzacasa G (1979) New data on the Upper Ordovician acid plutonism in the Eastern Alps. N Jb Mineral Abh 137: 162-183

Romer RL (2001) Lead incorporation during crystal growth and the minterpretation of geochronological data from low- ${ }^{238} \mathrm{U} /{ }^{204} \mathrm{~Pb}$ metamorphic minerals. Terra Nova 13: 258-263

Romer RL (2003) Alpha--recoil in U-Pb geochronology: effective sample size matters. Contrib Mineral Petrol 145: 481-491

Romer RL, Franz L (1998) Ordovivian Barrow-type metamorphism in the Strona-Ceneri Zone (Northern Italy) dated by U-Pb on staurolite. Schweiz Mineral Petrol Mitt 87: 383-395

Romer RL, Siegesmund S (2003) Why allanite may swindle about its true age. Contrib Mineral Petrol 146: 297-307

Romer RL and Thomas R (2005) U-Pb dating of micro-inclusions: The age of the Ehrenfriedersdorf tin deposit (Erzgebirge, Germany). In: Mao Jingwen and Bierlein FP (eds) Mineral Deposits Research: Meeting the Global Challenge. Proc 8th Biennial SGA Meeting, Beijing, China, pp. 817-820

Sander B (1929) Note illustrative della carta geologica delle Tre Venezie, foglio Bressanone 1:100,000. Ufficio Idrografico Mag Sez. Geol 56: 1-60

Sassi FP, Zanfrerari A (1972) Il significato geologico del Complesso de Thurtaler (Pustertal) con particolare riguardo alla succesione di eventi metamorphici prealpini nel basamento austridico delle Alpe Orientali. Boll Soc Geol Ital 91: 533-557 
Sassi FP, Cavazzini G, Visona D, Del Moro A (1985) Radiometric geochronology in the Eastern Alps: results and problems. Rend Soc Ital Min Petr 40:187-224

Satir M (1975) Die Entwicklungsgeschichte der westlichen Hohen Tauern und der südlichen Oetztalmasse auf Grund radiometrischer Altersbestimmungen. Mem Ist Geol Min Univ Padova 30: $82 \mathrm{pp}$

Schönhofer R (1999) Das ostalpine Altkristallin der westlichen Lasörlinggruppe (Osttirol, Österreich): Kartierung, Stoffbestand und tektonometamorphe Entwicklung. Erlanger Geol Abh 130: 1-128

Schönlaub HP (1979) Das Paläozoikum in Österreich. Abh Geol Bundesanstalt 33:1-124

Schönlaub HP (1993) Stratigraphy, biogeography and climate relationships of the Alpine Palaeozoic. In: von Raumer J, Neubauer F (eds). The pre-Mesozoic geology in the Alps. Springer, Berlin Heidelberg New York, pp 65-92

Schulz B (1991) Deformation und Metamorphose im Thurntaler Komplex (Ostalpen). Jb Geol BA 134: 369-391

Schulz B (1995) Geochemistry and REE magmatic fractionation patterns in the Prijakt amphibolitized eclogites of the Schobergruppe. Austroalpine basement (Eastern Alps). Schweiz Mineral Petrogr Mitt 77: 281-297

Schulz B (1997) Pre-Alpine tectonometamorphic evolutionin the Austroalpine basement to the south of the Tauern Window. Jb Geol B-A 143: 303-321

Schulz B, Bombach K (2003) Single zircon Pb-Pb geochronology of the Early-Paleozoic magmatic evolution in the Austroalpine basement to the south of the Tauern Window. Jb Geol B-A 143: 303-321

Schulz B, Nollau G, Heinisch H, Godizart G (1993) Austro-Alpine basement complex to the south of the Tauern Window. In: von Raumer J, Neubauer F (eds). The pre-Mesozoic geology in the Alps. Springer, Berlin Heidelberg New York, pp $493-512$

Schulz B, Siegesmund S, Steenken A, Schönhofer R, Heinrichs T (2001) Geologie des ostalpinen Kristallins südlich des Tauernfensters zwischen Virgental und Pustertal. Z Dtsch Geol Ges 152: 261-307

Schulz B, Bombach K, Pawlig S, Brätz H (2004) Neoproterozoic to Early-Paläozoic magmatic evolution in the Gondwana-derived Austroalpine basement to the south of the Tauern Window (Eastern Alps) Int J Earth Sci 93: 824-843 
Schuster R, Scharbert S, Abart R, Frank W (2001) Permo-Triassic extension and related HAT/LP metamorphism in the Austroalpine-Southalpine realm. Mitt Ges Geol Bergbaustud Österr 45: $111-141$

Sisson VB, Onstott TC (1986) Dating blueschist metamorphism; a combined ${ }^{40} \mathrm{Ar} /{ }^{39} \mathrm{Ar}$ and electron microprobe approach. Geochim Cosmochim Acta 50: 2111-2117

Sprenger W (1996) Das periadriatische Lineament suedlich der Lienzer Dolomiten; Strukturgeologie, Fernerkundung, Geochemie. Abh Geol B-A 52: 220 pp

Stampfli G, Mosar M (1998) Plate tectonics of the western Tethyan regions. Annales Geophysicae 16 (Suppl 1): 16p

Steenken A, Siegesmund S (2000) Evidence for an alkaline basaltic volcanism at the northern margin of Gondwana within the Austroalpjne Basement Complex of the Eastern Alps (Austrian/Italian border). Jb Geol B-A 142: 235-247

Steenken A, Siegesmund S, Heinrichs T, Fügenschuh B (2002) Cooling and exhumation of the Rieserferner Pluton (Eastern Alps, Italy/Austria). Int J Earth Sci 91: 799-817

Steiger R H, Jäger E (1977) Convention on the use of decay constants in geo- and cosmochronology. Earth Planet Sci Lett 36: 359-362

Stöckhert B (1982) Deformation und retrograde Metamorphose im Altkristallin S' des westlichen Tauernfensters (Südtirol). Diss Univ Elangen-Nürnberg, 214 pp

Stöckhert B (1984) K-Ar determinations on muscovites and phengites and the minimum age of the Old Alpine deformation in the Austridic basement south of the Tauern Window (Ahrn valley, Southern Tyrol, Eastern Alps). N Jb Min Abh 150: 103-120

Stöckhert B (1984) K-Ar determinations on muscovites and phengites and the minimum age of the Old Alpine deformation in the Austridic basement south of the Tauern Window (Ahrn valley, Southern Tyrol, Eastern Alps). N Jb Min Abh 150:103-120

Tera F, Wasserburg GJ (1972) Th-Pb Systematics in three APOLLO 14 basalts and the problem of initial $\mathrm{Pb}$ in Lunar rocks. Earth Planet Sci Lett 14: 281-304

Thöni M (1999) A review of geochronological data from the Eastern Alps. Schweiz Mineral Petrogr Mitt 79: 209-230

Thöni M (2002) Sm-Nd isotope systematics in garnet from different lithologies (Eastern Alps): age results, and an evaluation of potential problems for garnet Sm-Nd chronometry. Chem Geol 185: $255-281$ 
Tilton GR (1973) Isotopic lead ages of chondritic meteorites. Earth Planet Sci Lett 19: 321-329

Troll G, Forst R, Söllner F, Brack W, Köhler H, Müller-Sohnius D (1976) Über Bau, Alter und Metamorphose des Altkristallins der Schobergruppe, Osttirol. Geol. Rundsch 65: 483-511

Troll G, Baumgartner S, Daiminger W (1980) Zur Geologie der südwestlichen Schobergruppe, Osttirol. Geol Rdsch 65:483-511

von Raumer JF (1998) The Paleozoic evolution in the Alps: from Gondwana to Pangea. Int J Earth Sci 87: 407-435

von Raumer JF, Neubauer F (1993) Late Precambrian and Palaeozoic evolution of the Alpine basement - an overview. In: von Raumer JF, Neubauer F (eds) Pre-Mesozoic geology of the Alps. Springer, pp 625-639

von Raumer JF, Stampfli GM, Bussy F (2003) Gondwana-derived microcontinents: the constituents of the Variscan and Alpine collision orogens. Tectonophysics 365: 7-22

von Raumer JF, Stampfli GM, Borel G, Bussy F (2002) Organization of pre-Variscan basement areas at the north-Gondwanan margin. Int J Earth Sci 91: 35-52

Williams IS, Claesson S (1987) Isotopic evidence for the Precambrian provenance and Caledonian metamorphism of high grade paragneisses from the Seve Nappes, Scandinavian Caledonides. II. Ion microprobe zircon U-Th-Pb. Contrib Mineral Petrol 97: 205-217

Winchester JA, Floyd MD (1977) Geochemical discrimination of different magma series and their differentiation products using immobile elements. Chem Geol 20:325-343

Ziegler JF, Biersack JP, Littmark U (1985) The stopping and range of ions in solids. In: Ziegler JF (ed) The stopping and range of ions in matter. Vol 1, Pergamon 
Table 1. Compiled geochronological data from the pre-Mesozoic basement in the Eastern Alps.

\begin{tabular}{|c|c|c|c|}
\hline Rock Unit & Applied methods & Age $[\mathrm{Ma}]$ & Reference \\
\hline \multicolumn{4}{|l|}{ Middle Austroalpine nappe complex } \\
\hline Gleinalm-Rennfeld: paragneiss & Conventional $\mathrm{U} / \mathrm{Pb}$ zircon & $450-425$ & Neubauer et al. (2002) \\
\hline trondhjemite & Conventional $\mathrm{U} / \mathrm{Pb}$ zircon & $363-353$ & Neubauer et al. (2002) \\
\hline \multirow[t]{3}{*}{ Goldeck/Schober group: orthogneisses } & Conventional $\mathrm{U} / \mathrm{Pb}$ zircon & $455 \pm 4$ & Bücksteeg (1999) \\
\hline & $\mathrm{Pb} / \mathrm{Pb}$ zircon evaporation & $478 \pm 15,463 \pm 8$ & Schulz et al. (2004) \\
\hline & $\mathrm{Pb} / \mathrm{Pb}$ zircon evaporation & $457 \pm 5,448 \pm 5.5$ & Schulz et al. (2004) \\
\hline eclogite & $\mathrm{Pb} / \mathrm{Pb}$ zircon evaporation & $590 \pm 4$ & Schulz et al. (2004) \\
\hline amphibole-plagioclase gneiss & $\mathrm{Pb} / \mathrm{Pb}$ zircon evaporation & $554-525$ & Schulz et al. (2004) \\
\hline Campo Tures: orthogneiss & $\mathrm{Rb} / \mathrm{Sr}$ whole rock isochron & $445 \pm 24$ & Hammerschmidt (1981) \\
\hline \multirow[t]{5}{*}{ Antersellva-Casies: orthogneiss } & $\mathrm{Rb} / \mathrm{Sr}$ whole rock isochron & $434 \pm 4$ & Borsi et al. (1973) \\
\hline & Conventional U/Pb zircon & $443 \pm 16,424 \pm 11$ & Cliff (1980) \\
\hline & $\mathrm{Pb} / \mathrm{Pb}$ zircon evaporation & $486 \pm 4.5$ & Schulz and Bombach (2003) \\
\hline & $\mathrm{Rb} / \mathrm{Sr}$ muscovite & $308-294$ & Borsi et al. (1973) \\
\hline & $\mathrm{Rb} / \mathrm{Sr}$ biotite & $299-286$ & Borsi et al. (1973) \\
\hline \multirow[t]{2}{*}{ paragneiss/micashist } & $\mathrm{Rb} / \mathrm{Sr}$ whole rock isochron & $497 \pm 38$ & Borsi et al. (1973) \\
\hline & $\mathrm{Rb} / \mathrm{Sr}$ biotite & $294-280$ & Borsi et al. (1973) \\
\hline \multirow{5}{*}{$\begin{array}{l}\text { Thurntaler phyllite group: } \\
\text { meta-porphyroids } \\
\text { Ötztal basement: Winnbach migmatite } \\
\text { eclogite }\end{array}$} & & & \\
\hline & $\mathrm{Pb} / \mathrm{Pb}$ zircon evaporation & $473 \pm 7,478 \pm 6$ & Schulz et al. (2004) \\
\hline & $\mathrm{U} / \mathrm{Pb}$ zircon evaporation & $490 \pm 9$ & Klötzli-Chowanetz et al. (1997) \\
\hline & $\begin{array}{l}\text { Conventional U/Pb zircon } \\
\text { and SHRIMP }\end{array}$ & $481 \pm 9$ & Gebauer and Söllner (1993) \\
\hline & $\mathrm{Sm} / \mathrm{Nd}$ WR-garnet & $373 \pm 20,359 \pm 18$ & Miller and Thöni (1995) \\
\hline metapelite & Sm/Nd WR-garnet & $343 \pm 2-331 \pm 3$ & Hoinkes et al. (1997) \\
\hline \multirow[t]{3}{*}{ various orthogneisses } & $\mathrm{Pb} / \mathrm{Pb}$ zircon evaporation & $485 \pm 3$ & Bernhard et al. (1996) \\
\hline & Sm/Nd WR-titanite & $487 \pm 5$ & Bernhard et al. (1996) \\
\hline & Sm/Nd WR-apatite & $455 \pm 8$ & Hoinkes et al. (1997) \\
\hline \multirow[t]{2}{*}{ Ultental basement: ultramafic rocks } & $\mathrm{Sm} / \mathrm{Nd}$ whole rock isochron & $523 \pm 67$ & Thöni (1999) \\
\hline & Convetional U/Pb zircon & $336-332$ & Gebauer and Grünenfelder (1978) \\
\hline garnet-lherzolite & Sm/Nd WR-garnet & c. 340 & Thöni (1999) \\
\hline orthogneiss & Sm/Nd WR-garnet & $399 \pm 1$ & Hauzenberger et al. (1996) \\
\hline paragneiss & $\mathrm{Sm} / \mathrm{Nd}$ WR-garnet & $351 \pm 1$ & Hauzenberger et al. (1996) \\
\hline \multicolumn{4}{|l|}{ Upper Austroalpine nappe complex } \\
\hline Kaintaleck m. c.: hornblende gneiss & Conventoinal $\mathrm{U} / \mathrm{Pb}$ zircon & c. 510, c. 390 & Neubauer and Frisch (1993) \\
\hline Silvretta nappe: diorite & Convetional U/Pb zircon & $609 \pm 3$ & Schaltegger et al (1997) \\
\hline mafic rocks & $\mathrm{Pb} / \mathrm{Pb}$ zircon evaporation & $568 \pm 6$ & Müller et al. (1995) \\
\hline Flüela-orthogneisses & Conventional $\mathrm{U} / \mathrm{Pb}$ zircon & $450-420$ & Liebetrau (1996) \\
\hline
\end{tabular}


Table 2. Summary of SHRIMP U-Pb zircon data ${ }^{a}$ from metamorphic rocks of the pre-Mesozoic basement south of the Tauern Window, Eastern Alps, Austria.

\begin{tabular}{|c|c|c|c|c|c|c|c|c|c|c|c|c|c|c|}
\hline \multirow{3}{*}{$\begin{array}{c}\text { Grain- } \\
\text { Spot }\end{array}$} & \multicolumn{3}{|c|}{$\begin{array}{l}\text { Concentrations } \\
{[\mathrm{ppm}]}\end{array}$} & \multicolumn{7}{|c|}{ Measured Ratios ${ }^{\mathbf{b}}$} & \multicolumn{2}{|c|}{ Radiogenic Ratios $^{\mathbf{b}}$} & \multicolumn{2}{|c|}{ Ages $[\mathrm{Ma}]^{\mathbf{b}}$} \\
\hline & \multirow{2}{*}{ U } & \multirow{2}{*}{ Th } & \multirow{2}{*}{$\mathrm{Pb}_{\mathrm{rad}}$} & \multirow{2}{*}{$\frac{\mathrm{Th}}{\mathrm{U}}$} & \multirow{2}{*}{$\frac{{ }^{206} \mathrm{~Pb}}{{ }^{204} \mathrm{~Pb}}$} & \multirow{2}{*}{$\begin{array}{l}f_{206}{ }^{c} \\
{[\%]}\end{array}$} & \multirow{2}{*}{$\frac{{ }^{238} \mathrm{U}}{{ }^{206} \mathrm{~Pb}}$} & \multirow[b]{2}{*}{ \pm} & \multirow{2}{*}{$\frac{{ }^{207} \mathrm{~Pb}}{{ }^{206} \mathrm{~Pb}}$} & \multirow[b]{2}{*}{ \pm} & \multirow{2}{*}{$\frac{{ }^{206} \mathrm{~Pb}}{{ }^{238} \mathrm{U}}$} & \multirow[b]{2}{*}{ \pm} & \multirow{2}{*}{$\frac{{ }^{206} \mathrm{~Pb}}{{ }^{238} \mathrm{U}}$} & \multirow[b]{2}{*}{ \pm} \\
\hline & & & & & & & & & & & & & & \\
\hline \multicolumn{15}{|c|}{ Sample P1 (Porphyroid, Anras Valley) } \\
\hline $1-1$ & 179 & 99 & 14 & 0.55 & 0.001214 & 1.52 & 13.06 & 0.20 & 0.0688 & 0.0008 & 0.0754 & 0.0012 & 469 & 7 \\
\hline $2-1^{d}$ & 18 & 29 & 2 & 1.58 & 0.002144 & 7.02 & 9.43 & 0.30 & 0.1134 & 0.0043 & 0.0986 & 0.0032 & 606 & 19 \\
\hline $2-2$ & 371 & 58 & 26 & 0.16 & 0.000960 & 1.71 & 13.06 & 0.18 & 0.0703 & 0.0010 & 0.0753 & 0.0010 & 468 & 6 \\
\hline $3-1^{\mathrm{d}}$ & 393 & 104 & 32 & 0.26 & 0.000316 & 0.62 & 12.05 & 0.16 & 0.0615 & 0.0008 & 0.0825 & 0.0011 & 511 & 6 \\
\hline $4-1$ & 585 & 220 & 46 & 0.38 & 0.000215 & 0.37 & 12.82 & 0.16 & 0.0595 & 0.0005 & 0.0777 & 0.0010 & 482 & 6 \\
\hline $5-1$ & 260 & 86 & 20 & 0.33 & 0.000446 & 0.55 & 13.05 & 0.19 & 0.0610 & 0.0008 & 0.0762 & 0.0011 & 474 & 7 \\
\hline $6-1$ & 137 & 65 & 11 & 0.47 & 0.000469 & 1.07 & 12.72 & 0.20 & 0.0652 & 0.0009 & 0.0778 & 0.0012 & 483 & 7 \\
\hline $7-1$ & 106 & 23 & 8 & 0.22 & 0.001093 & 1.55 & 12.84 & 0.24 & 0.0691 & 0.0016 & 0.0767 & 0.0014 & 476 & 9 \\
\hline $8-1$ & 100 & 47 & 8 & 0.47 & 0.000831 & 1.54 & 12.71 & 0.24 & 0.0690 & 0.0015 & 0.0775 & 0.0015 & 481 & 9 \\
\hline $9-1$ & 231 & 25 & 17 & 0.11 & 0.000515 & 0.81 & 12.78 & 0.20 & 0.0631 & 0.0010 & 0.0776 & 0.0012 & 482 & 7 \\
\hline $10-1$ & 231 & 69 & 18 & 0.30 & 0.000503 & 0.66 & 12.89 & 0.19 & 0.0618 & 0.0008 & 0.0771 & 0.0012 & 478 & 7 \\
\hline $11-1$ & 472 & 49 & 34 & 0.10 & 0.000188 & 0.19 & 13.00 & 0.20 & 0.0580 & 0.0005 & 0.0768 & 0.0012 & 477 & 7 \\
\hline $12-1$ & 151 & 48 & 12 & 0.32 & 0.000869 & 1.29 & 12.83 & 0.21 & 0.0670 & 0.0010 & 0.0769 & 0.0013 & 478 & 8 \\
\hline $13-1$ & 113 & 67 & 9 & 0.59 & 0.000524 & 1.57 & 13.02 & 0.22 & 0.0693 & 0.0012 & 0.0756 & 0.0013 & 470 & 8 \\
\hline $14-1$ & 98 & 45 & 8 & 0.46 & 0.001053 & 1.97 & 12.83 & 0.25 & 0.0724 & 0.0018 & 0.0764 & 0.0015 & 475 & 9 \\
\hline $15-1$ & 383 & 61 & 28 & 0.16 & 0.000292 & 0.50 & 13.04 & 0.19 & 0.0606 & 0.0008 & 0.0763 & 0.0011 & 474 & 7 \\
\hline $16-1$ & 170 & 90 & 14 & 0.53 & 0.000546 & 1.03 & 12.92 & 0.20 & 0.0649 & 0.0009 & 0.0766 & 0.0012 & 476 & 7 \\
\hline $17-1$ & 119 & 31 & 9 & 0.26 & 0.000421 & 1.18 & 12.53 & 0.23 & 0.0661 & 0.0010 & 0.0789 & 0.0015 & 489 & 9 \\
\hline \multicolumn{15}{|c|}{ Sample BS3 (Orthogneiss, Barenle-Lake) } \\
\hline $1-1^{d}$ & 1000 & 33 & 123 & 0.03 & 0.000073 & 1.67 & 7.09 & 0.08 & 0.0700 & 0.0004 & 0.1387 & 0.0016 & 837 & 9 \\
\hline $2-1$ & 232 & 34 & 16 & 0.15 & 0.000319 & 1.11 & 13.32 & 0.21 & 0.0655 & 0.0010 & 0.0743 & 0.0012 & 462 & 7 \\
\hline $3-1^{d}$ & 830 & 295 & 66 & 0.36 & 0.000157 & 0.12 & 12.64 & 0.17 & 0.0575 & 0.0005 & 0.0790 & 0.0010 & 490 & 6 \\
\hline $4-1^{d}$ & 891 & 142 & 325 & 0.16 & 0.000028 & 0.08 & 2.75 & 0.04 & 0.1237 & 0.0007 & 0.3628 & 0.0047 & 1995 & 22 \\
\hline $5-1^{d}$ & 1370 & 276 & 96 & 0.20 & 0.000162 & 0.10 & 13.76 & 0.16 & 0.0573 & 0.0003 & 0.0726 & 0.0009 & 452 & 5 \\
\hline $6-1$ & 167 & 80 & 13 & 0.48 & 0.000718 & 1.08 & 12.86 & 0.19 & 0.0653 & 0.0010 & 0.0770 & 0.0012 & 478 & 7 \\
\hline $6-2$ & 1225 & 269 & 90 & 0.22 & 0.000091 & 0.09 & 13.24 & 0.16 & 0.0572 & 0.0004 & 0.0755 & 0.0009 & 469 & 6 \\
\hline $7-1$ & 800 & 234 & 60 & 0.29 & 0.000163 & 0.15 & 13.09 & 0.16 & 0.0578 & 0.0004 & 0.0763 & 0.0009 & 474 & 6 \\
\hline $8-1$ & 528 & 160 & 39 & 0.30 & 0.000137 & 0.27 & 13.38 & 0.17 & 0.0587 & 0.0006 & 0.0745 & 0.0009 & 463 & 6 \\
\hline $9-1$ & 524 & 188 & 40 & 0.36 & 0.000165 & 0.46 & 13.09 & 0.18 & 0.0602 & 0.0005 & 0.0761 & 0.0010 & 473 & 6 \\
\hline $10-1$ & 2065 & 721 & 159 & 0.35 & 0.000035 & 0.10 & 13.04 & 0.15 & 0.0573 & 0.0003 & 0.0766 & 0.0009 & 476 & 5 \\
\hline $11-1$ & 592 & 205 & 45 & 0.35 & 0.000200 & 0.35 & 13.13 & 0.17 & 0.0593 & 0.0004 & 0.0759 & 0.0010 & 472 & 6 \\
\hline $12-1$ & 2370 & 996 & 180 & 0.42 & 0.000028 & 0.10 & 13.39 & 0.15 & 0.0573 & 0.0004 & 0.0746 & 0.0009 & 464 & 5 \\
\hline $13-1$ & 896 & 296 & 62 & 0.33 & 0.000120 & 0.28 & 14.48 & 0.18 & 0.0588 & 0.0004 & 0.0689 & 0.0008 & 429 & 5 \\
\hline $14-1$ & 2350 & 765 & 177 & 0.33 & 0.000036 & 0.11 & 13.26 & 0.16 & 0.0574 & 0.0003 & 0.0753 & 0.0009 & 468 & 5 \\
\hline $15-1^{d}$ & 1180 & 333 & 85 & 0.28 & 0.000053 & 0.19 & 13.65 & 0.16 & 0.0580 & 0.0003 & 0.0731 & 0.0009 & 455 & 5 \\
\hline $16-1$ & 837 & 234 & 63 & 0.28 & 0.000080 & 0.26 & 12.99 & 0.16 & 0.0586 & 0.0004 & 0.0768 & 0.0010 & 477 & 6 \\
\hline
\end{tabular}

a Zircon concentrates were obtained from the bulk samples using standard mineral-separation procedures. Selected grains were mounted in epoxy together with zircon standard AS3 (Duluth Complex gabbroic anorthosite; Paces and Miller, 1989) and the RSES standard SL13. The grains were then sectioned approximately in half, polished and photographed. All zircons were examined by cathodoluminescence imaging prior to the subsequent ion microprobe session. The SHRIMP data have been reduced in a manner similar to that by Compston et al. (1992) and Williams and Claesson (1987). U/Pb in the unknowns were normalised to a ${ }^{206} \mathrm{~Pb} /{ }^{238} \mathrm{U}$ value of 0.1859 (equivalent to an age of $1099.1 \mathrm{Ma}$ ) for AS3. The $\mathrm{U}$ and Th concentrations were determined relative to those measured in the SL13 standard. $\mathrm{Pb} / \mathrm{U}$ ages for the Palaeozoic Alpine zircons are calculated from the ${ }^{206} \mathrm{~Pb} /{ }^{238} \mathrm{U}$ compositions, with the corrections for common $\mathrm{Pb}$ made using the measured ${ }^{207} \mathrm{~Pb} /{ }^{206} \mathrm{~Pb}$ and ${ }^{206} \mathrm{~Pb} /{ }^{238} \mathrm{U}$ values following Tera and Wasserburg (1972) and as described in Compston et al. (1992). For the Palaeoproterozoic zircons ${ }^{207} \mathrm{~Pb} /{ }^{206} \mathrm{~Pb}$ ages are quoted or calculated, and common $\mathrm{Pb}$ corrections were made using the measured ${ }^{204} \mathrm{~Pb} /{ }^{206} \mathrm{~Pb}$ composition relevant model $\mathrm{Pb}$ composition from Cummings and Richards (1975)

b Uncertainties in the isotopic ratios and ages are reported at the $11_{-}$level.

c $\mathrm{f}_{206}[\%]$ is the percentage of total ${ }^{206} \mathrm{~Pb}$ that is common $\mathrm{Pb}$.

d Denotes this analysis was not included in the final age calculation (see Fig. 4). 
Table 3. U-Pb analytical data of staurolite and kyanite from metamorphic rocks of the pre-Mesozoic basement south of the Tauern Window, Eastern Alps, Austria.

\begin{tabular}{|c|c|c|c|c|c|c|c|c|c|c|c|c|c|c|}
\hline \multirow[t]{3}{*}{ Sample ${ }^{\mathbf{a}}$} & \multirow{3}{*}{$\begin{array}{l}\text { Weight } \\
{[\mathrm{mg}]}\end{array}$} & \multirow{2}{*}{\multicolumn{2}{|c|}{$\begin{array}{l}\text { Concentration } \\
{[\mathrm{ppm}]}\end{array}$}} & \multirow{2}{*}{$\begin{array}{c}\text { Meas. } \\
\text { ratios } \\
{ }^{206} \mathrm{~Pb}\end{array}$} & \multicolumn{3}{|c|}{ Isotope ratios $[\%]^{\mathbf{c}}$} & \multicolumn{4}{|c|}{ Atomic ratios $^{\mathbf{c}}$} & \multicolumn{3}{|c|}{ Apparent ages [Ma $]^{\complement}$} \\
\hline & & & & & ${ }^{206} \mathrm{~Pb}$ & ${ }^{207} \mathrm{~Pb}$ & ${ }^{208} \mathrm{~Pb}$ & ${ }^{238} \mathrm{U}$ & ${ }^{206} \mathrm{~Pb}$ & ${ }^{207} \mathrm{~Pb}$ & ${ }^{207} \mathrm{~Pb}$ & ${ }^{206} \mathrm{~Pb}$ & ${ }^{207} \mathrm{~Pb}$ & ${ }^{207} \mathrm{~Pb}$ \\
\hline & & 0 & & ${ }^{204} \mathrm{~Pb}$ & & & & ${ }^{204} \mathrm{~Pb}$ & ${ }^{238} \mathrm{U}$ & ${ }^{235} \mathrm{U}$ & ${ }^{206} \mathrm{~Pb}$ & ${ }^{238} \mathrm{U}$ & ${ }^{235} \mathrm{U}$ & ${ }^{206} \mathrm{~Pb}$ \\
\hline
\end{tabular}

\begin{tabular}{|c|c|c|c|c|c|c|c|c|c|c|c|c|c|c|c|}
\hline \multicolumn{16}{|c|}{ Staurolite1 } \\
\hline \multicolumn{16}{|c|}{ Common lead ${ }^{206} \mathrm{~Pb} /{ }^{204} \mathrm{~Pb}=18.64 \pm .12,{ }^{207} \mathrm{~Pb} /{ }^{204} \mathrm{~Pb}=15.72 \pm .05,{ }^{208} \mathrm{~Pb} /{ }^{204} \mathrm{~Pb}=37.6 \pm .2$} \\
\hline 1 & $\mathrm{H}_{2} \mathrm{O}$ & & 0.083 & 0.105 & 22.17 & 21.59 & 3.94 & 74.47 & 61 & 0.0574 & & & 360 & & \\
\hline 2 & 1N HBr & & 0.215 & 0.042 & 52.45 & 30.27 & 1.95 & 67.78 & 852 & 0.0420 & 0.3735 & 0.0645 & 265 & 322 & 757 \\
\hline 3 & $7 \mathrm{~N} \mathrm{HNO}_{3}$ & & 0.480 & 0.093 & 115.3 & 25.61 & 1.33 & 73.06 & 2140 & 0.0485 & 0.3472 & 0.0519 & 306 & 303 & 280 \\
\hline 4 & $6 \mathrm{~N} \mathrm{HCl}$ & & 0.105 & 0.014 & 33.84 & 64.09 & 3.43 & 32.48 & 661 & 0.0246 & 0.1821 & 0.0536 & 157 & 170 & 356 \\
\hline 5 & $20 \% \mathrm{HF}$ & & 0.087 & 0.135 & 20.24 & 37.39 & 3.90 & 58.71 & 43 & 0.0360 & & & 228 & & \\
\hline 6 & $\mathrm{HF}$ & & 0.344 & 0.031 & 36.14 & 58.01 & 3.19 & 38.80 & 1000 & 0.0181 & 0.1371 & 0.0551 & 115 & 131 & 415 \\
\hline 7 & $\mathrm{HCl}(2)$ & & 0.094 & 0.012 & 25.86 & 84.90 & 3.69 & 11.41 & 534 & 0.0139 & & & 89 & & \\
\hline \multirow[t]{3}{*}{8} & HF (2) & & 0.059 & 0.016 & 26.94 & 87.59 & 5.11 & 7.30 & 256 & 0.0335 & & & 212 & & \\
\hline & SUM $^{* *}$ & & 1.384 & 0.343 & 52.46 & & & & & 0.0344 & & & 218 & & \\
\hline & SUM & 13.96 & 1.467 & 0.448 & 45.36 & & & & & 0.0357 & & & 226 & & \\
\hline \multicolumn{16}{|c|}{ Staurolite 2} \\
\hline \multicolumn{16}{|c|}{ Common lead ${ }^{206} \mathrm{~Pb} /{ }^{204} \mathrm{~Pb}=18.31 \pm .12,{ }^{207} \mathrm{~Pb} /{ }^{204} \mathrm{~Pb}=15.66 \pm .05,{ }^{208} \mathrm{~Pb} /{ }^{204} \mathrm{~Pb}=37.5 \pm .3$} \\
\hline 9 & $\mathrm{H}_{2} \mathrm{O}$ & & 0.064 & 0.130 & 21.52 & 61.69 & 3.80 & 34.51 & 33 & 0.0964 & & & 594 & & \\
\hline 10 & $1 \mathrm{~N} \mathrm{HBr}$ & & 0.124 & 0.025 & 42.77 & 36.45 & 1.82 & 61.73 & 626 & 0.0417 & 0.2862 & 0.0498 & 263 & 256 & 188 \\
\hline 11 & $7 \mathrm{~N} \mathrm{HNO}_{3}$ & & 1.235 & 0.195 & 156.3 & 27.61 & 1.42 & 70.97 & 3160 & 0.0455 & 0.3225 & 0.0514 & 287 & 284 & 258 \\
\hline 12 & $6 \mathrm{~N} \mathrm{HCl}$ & & 0.052 & 0.008 & 45.36 & 53.64 & 2.75 & 43.61 & 727 & 0.0442 & 0.3122 & 0.0513 & 279 & 276 & 253 \\
\hline 13 & $20 \% \mathrm{HF}$ & & 0.045 & 0.103 & 20.99 & 62.38 & 4.08 & 33.54 & 29 & 0.0905 & & & 559 & & \\
\hline 14 & $\mathrm{HF}$ & & 0.419 & 0.032 & 67.65 & 87.24 & 4.84 & 7.92 & 1490 & 0.0348 & 0.2665 & 0.0555 & 221 & 240 & 432 \\
\hline 15 & $\mathrm{HCl}(2)$ & & 0.056 & 0.004 & 40.02 & 90.98 & 5.13 & 3.89 & 1260 & 0.0222 & 0.1727 & 0.0563 & 142 & 162 & 464 \\
\hline \multirow[t]{3}{*}{16} & HF (2) & & 0.094 & 0.005 & 84.99 & 92.36 & 5.22 & 2.42 & 2930 & 0.0339 & 0.2633 & 0.0565 & 215 & 238 & 471 \\
\hline & SUM** & & 2.025 & 0.372 & 98.98 & & & & & 0.0429 & & & 271 & & \\
\hline & SUM & 14.68 & 2.089 & 0.502 & 78.92 & & & & & 0.0445 & & & 281 & & \\
\hline \multicolumn{16}{|c|}{ Kyanite } \\
\hline \multicolumn{16}{|c|}{ Common lead ${ }^{206} \mathrm{~Pb} /{ }^{204} \mathrm{~Pb}=19.11 \pm .12,{ }^{207} \mathrm{~Pb} /{ }^{204} \mathrm{~Pb}=15.68 \pm .05,{ }^{208} \mathrm{~Pb} /{ }^{204} \mathrm{~Pb}=37.5 \pm .2$} \\
\hline 17 & $\mathrm{H}_{2} \mathrm{O}$ & & 0.037 & 0.002 & 51.65 & 95.04 & 4.91 & 0.05 & 1610 & 0.0284 & 0.2023 & 0.0517 & 180 & 187 & 272 \\
\hline 18 & $1 \mathrm{~N} \mathrm{HBr}$ & & 0.055 & 0.180 & 20.56 & 47.13 & 3.60 & 49.27 & 20 & 0.0705 & & & 439 & & \\
\hline 19 & $7 \mathrm{~N} \mathrm{HNO}_{3}$ & & 0.031 & 0.015 & 26.38 & 57.63 & 7.00 & 35.37 & 150 & 0.0493 & & & 310 & & \\
\hline 20 & $6 \mathrm{~N} \mathrm{HCl}$ & & 0.029 & 0.020 & 23.52 & 54.99 & 9.19 & 35.82 & 102 & 0.0427 & & & 270 & & \\
\hline 21 & $20 \% \mathrm{HF}$ & & 0.036 & 0.675 & 18.66 & & & & & & & & & & \\
\hline 22 & $\mathrm{HF}$ & & 0.102 & 0.025 & 33.07 & 90.28 & 3.99 & 5.73 & 318 & 0.0448 & & & 283 & & \\
\hline 23 & $\mathrm{HCl}(2)$ & & 0.040 & 0.003 & 35.83 & 92.71 & 5.58 & 1.71 & 1166 & 0.0176 & & & 113 & & \\
\hline \multirow[t]{3}{*}{24} & HF (2) & & 0.030 & 0.003 & 42.36 & 91.08 & 5.42 & 3.50 & 952 & 0.0311 & & & 198 & & \\
\hline & SUM** & & 0.323 & 0.921 & 19.79 & & & & & 0.0448 & & & 282 & & \\
\hline & SUM & 22.50 & 0.360 & 0.923 & 19.86 & & & & & 0.0397 & & & 251 & & \\
\hline
\end{tabular}

a Staurolite and kyanite concentrates were obtained using standard mineral-separation procedures and purified through separation by hand under the binocular. Although care was taken to use only fracture-free and apparently inclusion-free clear grains or fragments, BSE images demonstrate that essentially all staurolite samples have micro-inclusions of ilmenite, biotite, andesine, quartz, and rare zircon. Inclusions generally are less than 5 micron large. Optically clear and homogeneous grains in the size fraction 60-240 micron were used for a leaching experiment using $\mathrm{H}_{2} \mathrm{O}, 1 \mathrm{~N} \mathrm{HBr}, 7 \mathrm{~N} \mathrm{HNO}_{3}, 6 \mathrm{~N} \mathrm{HCl}, 20 \% \mathrm{HF}$, and concentrate HF. Samples were leached in closed Savillex beakers through various acids for $24 \mathrm{~h}$ at $150-160^{\circ} \mathrm{C}$ on the hot plate. Acids were pipetted away after centrifugation. The residue was rinsed twice with distilled water by resuspending it using an ultrasonic bath. After centrifugation, the $\mathrm{H}_{2} \mathrm{O}$ was pipetted away and combined with the corresponding leachate. ${ }^{205} \mathrm{~Pb}^{235} \mathrm{U}$ mixed tracer was added to each leachate and homogenized over night on the hot plate. $\mathrm{U}$ and $\mathrm{Pb}$ were separated the ion-exchange chromatographic procedure of Tilton (1973) and Manhès et al. (1973). $\mathrm{Pb}$ and $\mathrm{U}$ were loaded together on single Re-filaments using a silica-gel emitter and $\mathrm{H}_{3} \mathrm{PO}_{4}$ (Gerstenberger and Haase, 1997) and measured at $1200^{\circ}-1260^{\circ} \mathrm{C}$ and $1350-1400^{\circ} \mathrm{C}$, respectively, on a Finnigan MAT262 multicollector mass-spectrometer using Faraday collectors and ion counting. SUM $=$ sum of $\mathrm{U}$ and $\mathrm{Pb}$ content and weighted averages for ${ }^{206} \mathrm{~Pb} /{ }^{204} \mathrm{~Pb}$ and ${ }^{206} \mathrm{~Pb} /{ }^{238} \mathrm{U}$ and apparent ${ }^{206} \mathrm{~Pb} /{ }^{238} \mathrm{U}$ age. SUM** = as SUM, but after exclusion of $\mathrm{H}_{2} \mathrm{O}$-wash.

b Lead isotope ratios corrected for fractionation with $0.1 \%$ / a.m.u.

c Lead corrected for fractionation, blank, tracer contribution, and initial lead. During the measurement period total blanks were less than $15 \mathrm{pg}$ for lead and less than $1 \mathrm{pg}$ for uranium.

d Apparent ages were calculated using the constants of Jaffey et al. (1971) recommended by IUGS (Steiger and Jäger, 1977). 
Table 4. Lead isotope composition of staurolite and kyanite leachates and allanite bulk samples from the Austrian Alps.

\begin{tabular}{lccc}
\hline Sample $^{\mathbf{a}}$ & ${ }^{206} \mathrm{~Pb}^{\mathbf{b}}$ & ${ }^{207} \mathrm{~Pb}^{\mathbf{b}}$ & ${ }^{208} \mathrm{~Pb}^{\mathbf{b}}$ \\
& --- & --- & --- \\
& ${ }^{204} \mathrm{~Pb}$ & ${ }^{204} \mathrm{~Pb}$ & ${ }^{204} \mathrm{~Pb}$ \\
\hline
\end{tabular}

\section{Staurolite 1}

$\begin{array}{llccc}1 & \mathrm{H}_{2} \mathrm{O} & 22.14 & 16.36 & 49.66 \\ 2 & \mathrm{HBr} & 54.44 & 18.03 & 117.7 \\ 3 & \mathrm{HNO}_{3} & 122.5 & 21.11 & 334.0 \\ 4 & \mathrm{HCl} & 34.94 & 16.60 & 48.85 \\ 5 & \mathrm{HF}-20 \% & 20.20 & 15.89 & 40.04 \\ 6 & \mathrm{HF} & 36.76 & 16.72 & 49.71 \\ 7 & \mathrm{HCL} \text { grind } & 26.04 & 16.04 & 38.59 \\ 8 & \mathrm{HF} \text { grind } & 27.22 & 16.22 & 38.31\end{array}$

\section{Staurolite 2}

$\begin{array}{llccc}9 & \mathrm{H}_{2} \mathrm{O} & 21.49 & 15.86 & 39.27 \\ 10 & \mathrm{HBr} & 44.38 & 16.96 & 81.63 \\ 11 & \mathrm{HNO}_{3} & 162.2 & 23.05 & 407.3 \\ 12 & \mathrm{HCl} & 50.39 & 17.31 & 63.58 \\ 13 & \mathrm{HF}-20 \% & 20.95 & 15.83 & 38.91 \\ 14 & \text { HF } & 70.27 & 18.55 & 42.21 \\ 15 & \mathrm{HCL} \text { grind } & 46.34 & 17.24 & 38.70 \\ 16 & \text { HF grind } & 117.7 & 21.28 & 40.11\end{array}$

\section{Kyanite}

\begin{tabular}{lllll}
17 & $\mathrm{H}_{2} \mathrm{O}$ & 64.81 & 18.05 & 37.52 \\
18 & $\mathrm{HBr}$ & 20.55 & 15.79 & 38.99 \\
19 & $\mathrm{HNO}_{3}$ & 26.51 & 15.58 & 42.04 \\
20 & $\mathrm{HCl}$ & 23.49 & 16.41 & 40.35 \\
21 & $\mathrm{HF}-20 \%$ & 18.66 & 15.70 & 38.53 \\
22 & $\mathrm{HF}$ & 33.37 & 16.31 & 38.40 \\
23 & $\mathrm{HCL}$ grind & 39.67 & 16.92 & 37.88 \\
24 & $\mathrm{HF}$ grind & 48.75 & 17.44 & 38.64 \\
\hline
\end{tabular}

a Samples and sample numbers as in Table 3.

b Lead isotope analyses were performed at GeoForschungsZentrum Potsdam, Germany, using a Finnigan MAT262 multicollector mass spectrometer. The lead isotopic composition is corrected for mass discrimination with $0.1 \% /$ a.m.u. $2 \sigma$ uncertainties are less than $0.1 \%$. 


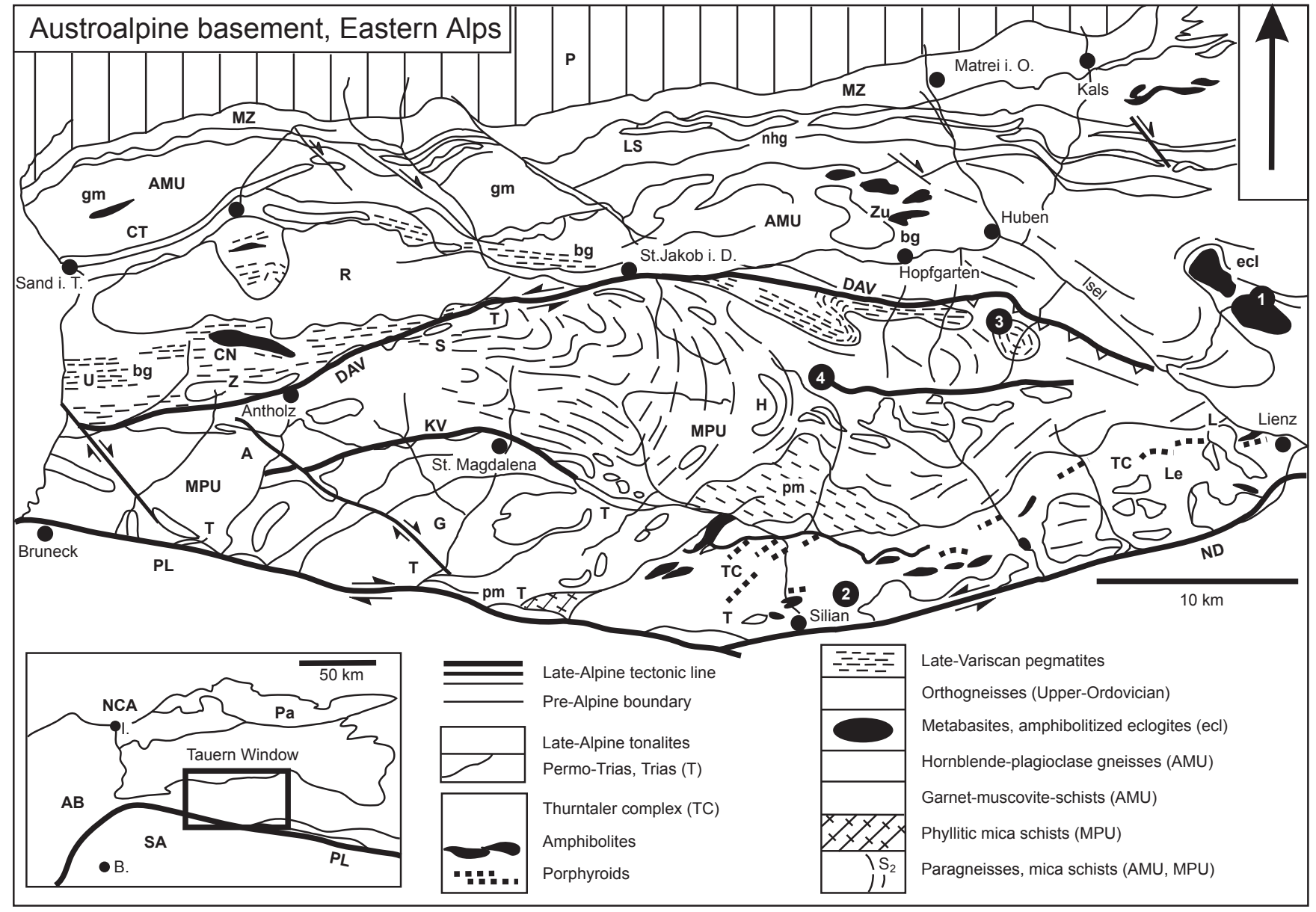



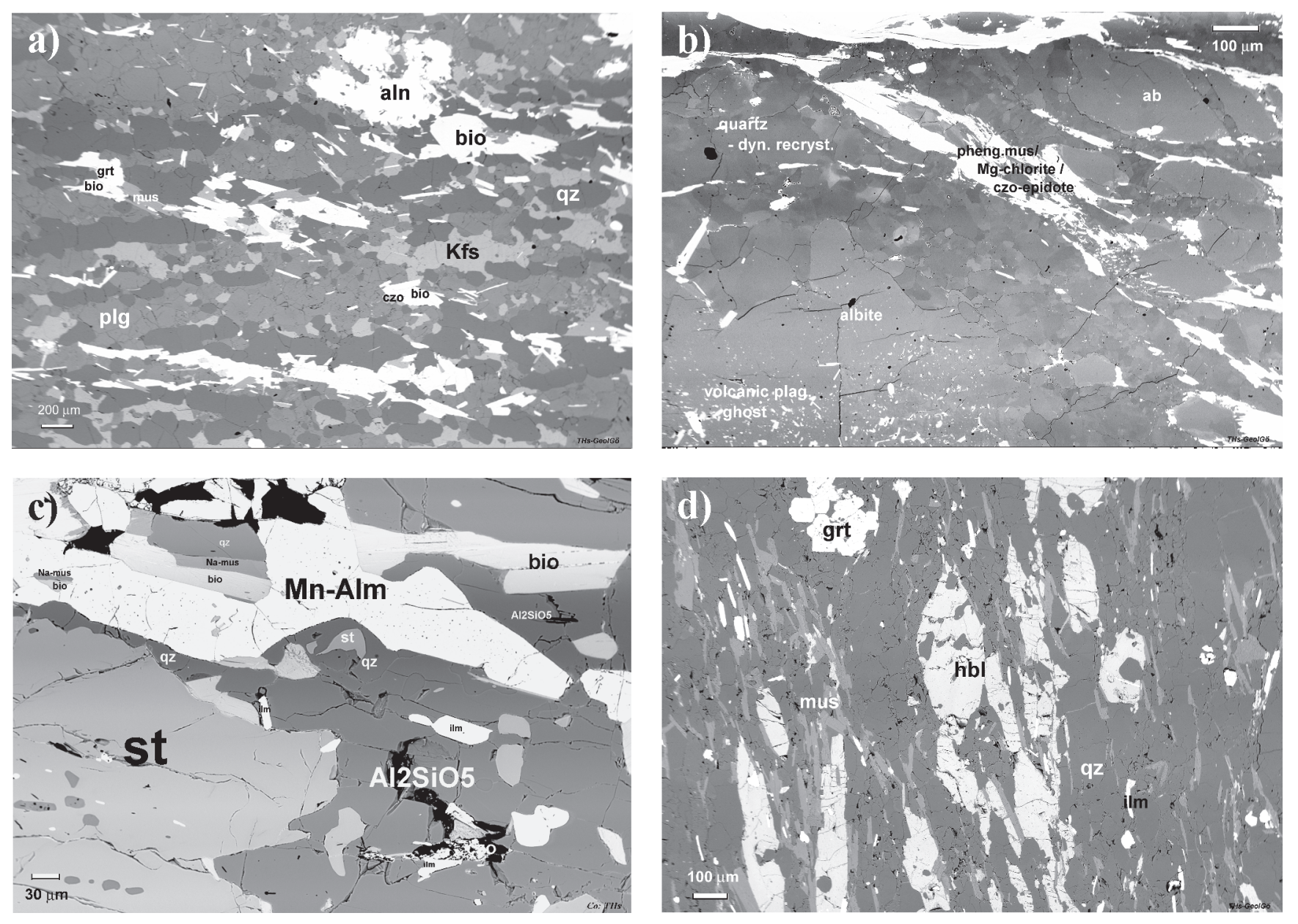


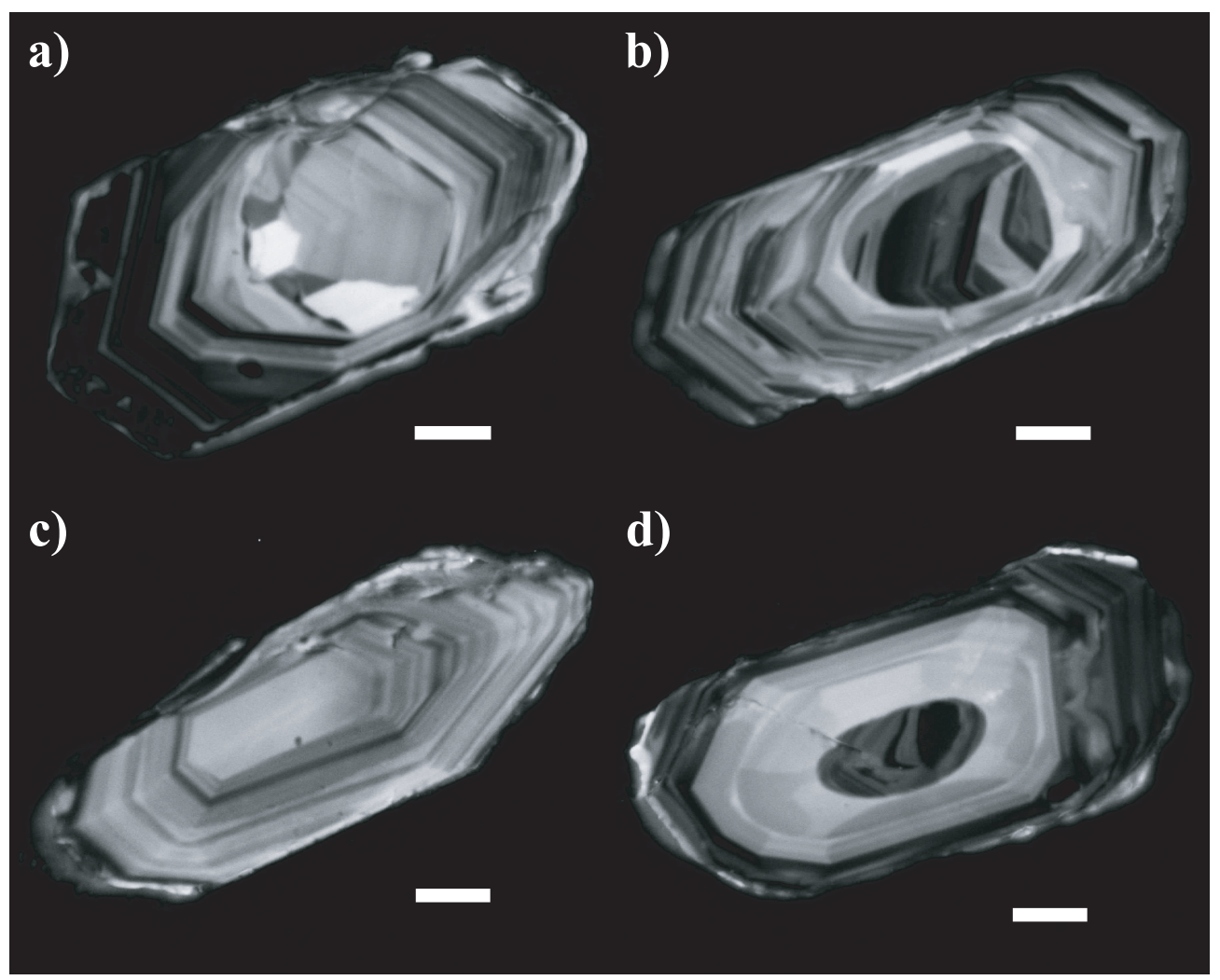



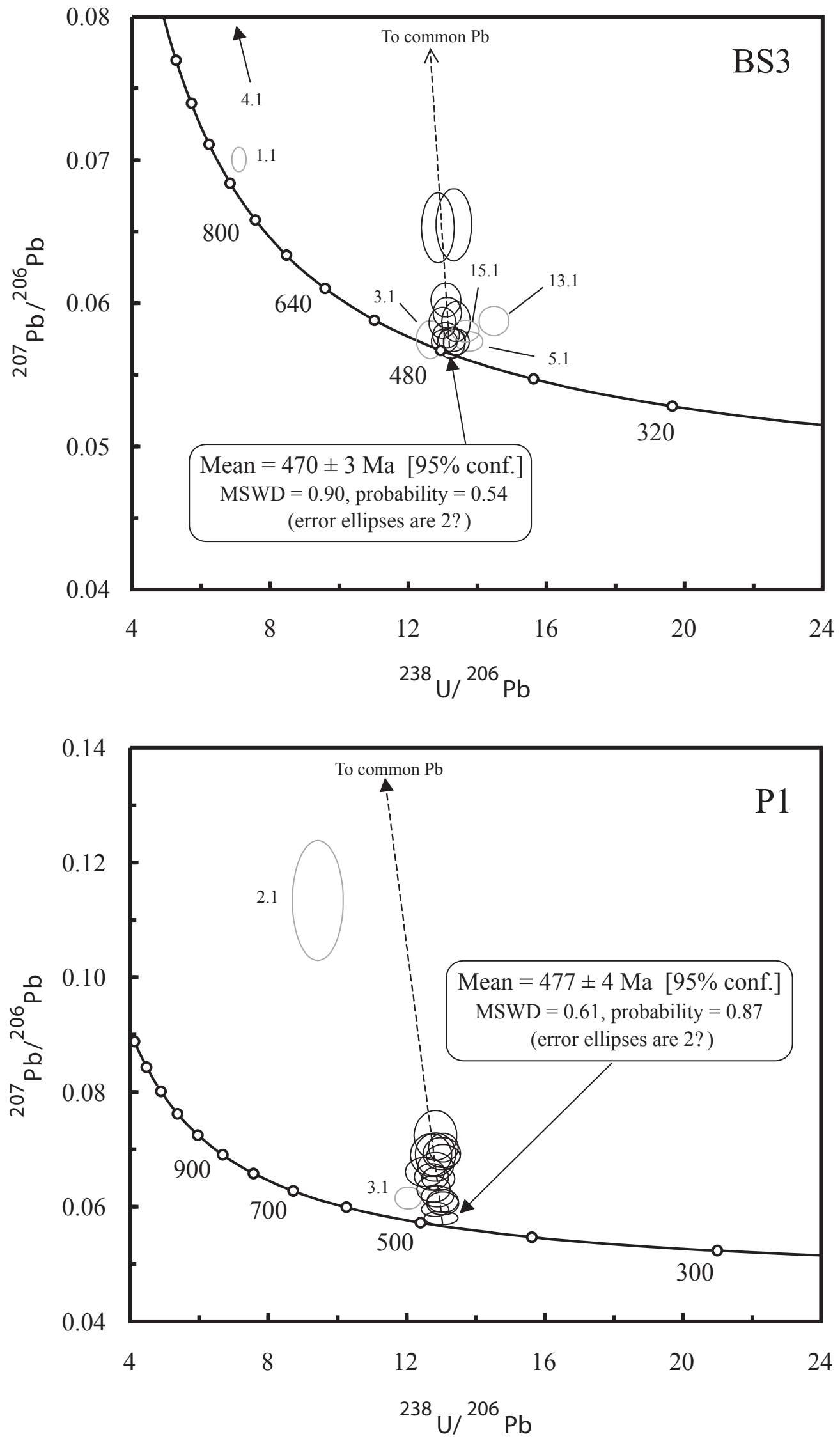

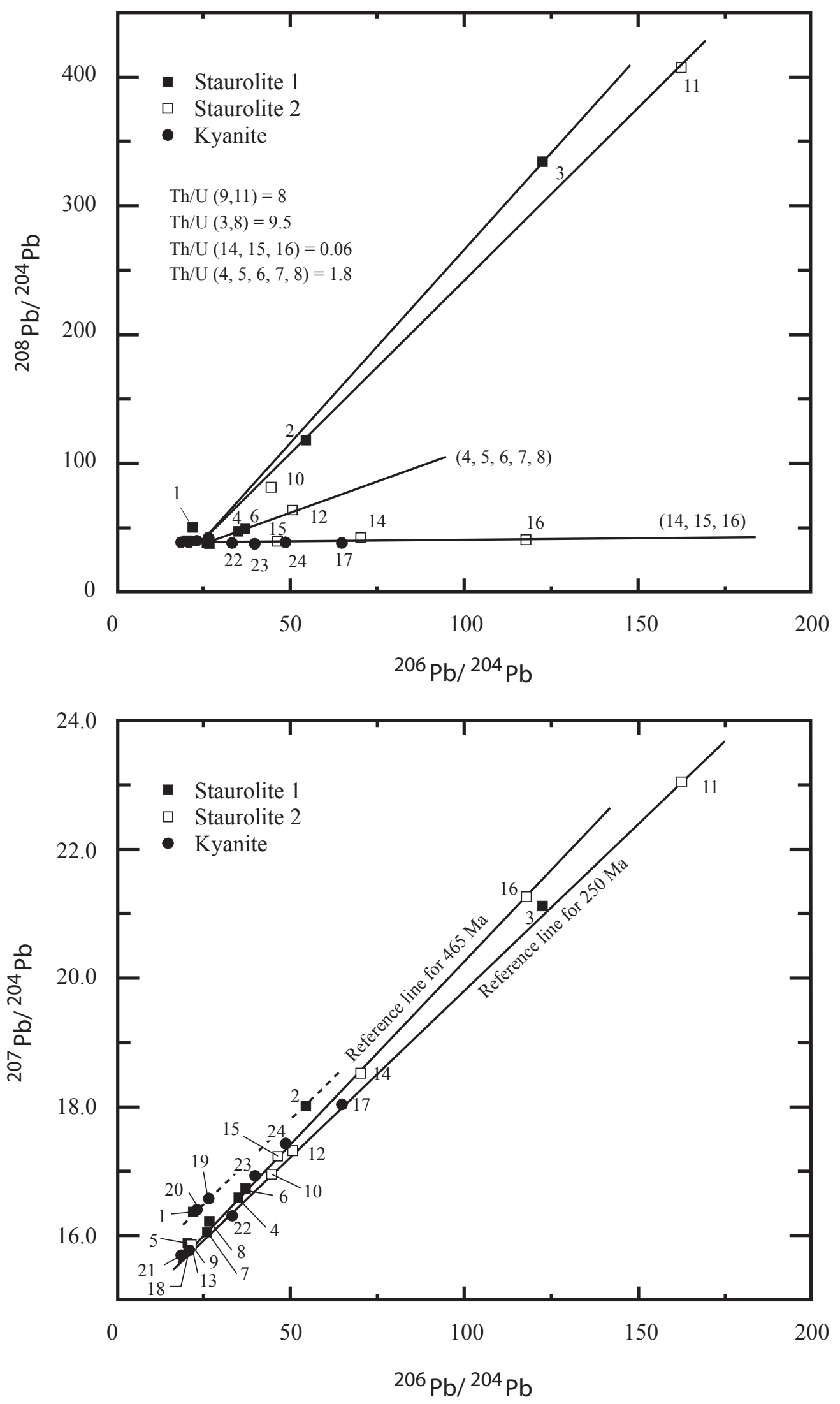


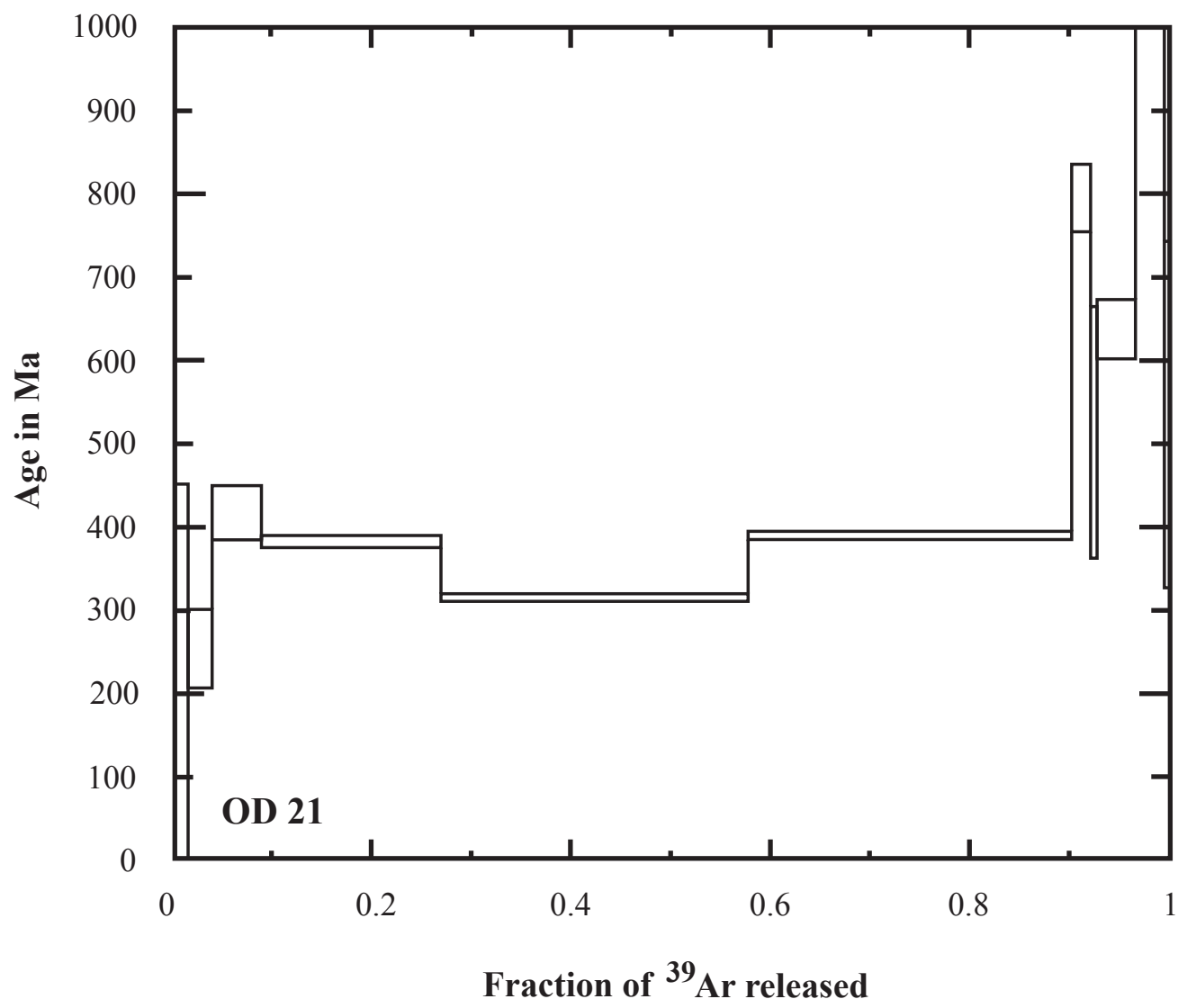

